\title{
In-vitro meat: a promising solution for sustainability of meat sector
}

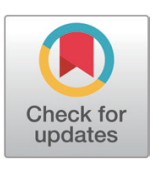

Received: Jun 2, 2021

Revised: Jun 21, 2021

Accepted: Jun 22, 2021

${ }^{*}$ Corresponding author

Neelesh Sharma

Division of Veterinary Medicine, Faculty of Veterinary Sciences \& Animal Husbandry, Sher-e-Kashmir University of Agricultural Sciences \& Technology of Jammu, R.S. Pura, UT of Jammu and Kashmir 181102, India Tel: +91-1923-252906

E-mail: drneelesh_sharma@yahoo.co.in

Copyright (C) 2021 Korean Society of Animal Sciences and Technology. This is an Open Access article distributed under the terms of the Creative Commons Attribution Non-Commercial License (http:// creativecommons.org/licenses/bync/4.0/) which permits unrestricted non-commercial use, distribution, and reproduction in any medium, provided the original work is properly cited.

ORCID

Pavan Kumar

https://orcid.org/0000-0002-0567-0359 Neelesh Sharma

https://orcid.org/0000-0003-3932-4064

Shubham Sharma

https://orcid.org/0000-0001-6530-2155 Nitin Mehta

https://orcid.org/0000-0002-8856-9490

Akhilesh Kumar Verma

https://orcid.org/0000-0002-3741-638X

\author{
Pavan Kumar ${ }^{1,2}$, Neelesh Sharma ${ }^{3 *}$, Shubham Sharma ${ }^{4}$, Nitin Mehta ${ }^{1}$, \\ Akhilesh Kumar Verma ${ }^{5}$, S Chemmalar ${ }^{6}$ and Awis Qurni Sazili ${ }^{2}$ \\ ${ }^{1}$ Department of Livestock Products Technology, College of Veterinary Science, Guru Angad Dev \\ Veterinary and Animal Sciences University, Ludhiana Punjab 141004, India \\ ${ }^{2}$ Institute of Tropical Agriculture and Food Security, Universiti Putra Malaysia, Serdang 43400, Malaysia \\ ${ }^{3}$ Division of Veterinary Medicine, Faculty of Veterinary Sciences \& Animal Husbandry, Sher-e-Kashmir \\ University of Agricultural Sciences \& Technology of Jammu, R.S. Pura, UT of Jammu and Kashmir 181102, India \\ ${ }^{4}$ Department of Livestock Production and Management, College of Veterinary Sciences \& Animal \\ Husbandry, Nanaji Deshmukh Veterinary Science University, Mhow, Madhya Pradesh 453446, India \\ ${ }^{5}$ Department of Livestock Products Technology, College of Veterinary and Animal Science, Sardar \\ Vallabhbhai Patel University of Agriculture and Technology, Meerut, Uttar Pradesh 250110, India \\ ${ }^{6}$ Natural Medicines and Product Research Laboratory, Institute of Bioscience, Universiti Putra Malaysia, \\ Serdang 43400, Malaysia
}

\section{Abstract}

The in-vitro meat is a novel concept in food biotechnology comprising field of tissue engineering and cellular agriculture. It involves production of edible biomass by in-vitro culture of stem cells harvested from the muscle of live animals by self-organizing or scaffolding methodology. It is considered as efficient, environmental friendly, better ensuring public safety and nutritional security, as well as ethical way of producing meat. Source of stem cells, media ingredients, supply of large size bioreactors, skilled manpower, sanitary requirements, production of products with similar sensory and textural attributes as of conventional meat, consumer acceptance, and proper set up of regulatory framework are challenges faced in commercialization and consumer acceptance of in-vitro meat. To realize any perceivable change in various socio-economic and environmental spheres, the technology should be commercialized and should be cost-effective as conventional meat and widely accepted among consumers. The new challenges of increasing demand of meat with the increasing population could be fulfill by the establishment of in-vitro meat production at large scale and its popularization. The adoption of in-vitro meat production at an industrial scale will lead to self-sufficiency in the developed world.

Keywords: Cell culture, Sustainability, Food neophobia, Consumer acceptance, Future prospects

\section{INTRODUCTION}

Meat has been an integral part of our diet and played an important role in socio-economic and cultural development of human society. Meat is an excellent source of high quality animal proteins containing all essential amino acids, source of energy, lipids, minerals, endogenous antioxidant compounds, and a range of bioactive compounds such as taurine, carnitine, carnosine, ubiquinone, glutathione, and creatine [1]. In addition to nutritional significance, meat has a unique place in our food basket due to unique 
S Chemmalar

https://orcid.org/0000-0003-3169-700X

Awis Qurni Sazili

https://orcid.org/0000-0002-7362-0855

\section{Competing interests}

No potential conflict of interest relevant to

this article was reported.

Funding sources

This research was supported by the project (No.: BT/PR26666/AAQ/1/713/2017) funded by the Department of Biotechnology, New

Delhi, Government of India.

\section{Acknowledgements}

Authors are equally thankful to Sher-eKashmir University of Agricultural Sciences \& Technology of Jammu, UT of Jammu and Kashmir, India.

\section{Availability of data and materia Upon reasonable request, the datasets of this study can be available from the corresponding author.}

\section{Authors' contributions}

Conceptualization: Kumar P, Sharma N Sazili AQ.

Writing - original draft: Kumar P, Sharma N, Mehta N

Writing - review \& editing: Kumar P, Sharma $\mathrm{N}$, Sharma S, Mehta N, Verma AK, Chemmalar S, Sazili AQ.

Ethics approval and consent to participate This article does not require IRB/IACUC approval because there are no human and animal participants. structures and compositional features imparting characteristic functionalities and technological attributes such as palatability, digestibility, organoleptic attributes, etc. [2].

In 2019, global meat production was recorded to $325 \mathrm{Mt}$, obtained from slaughtering of approximately 80 billion animals. It is projected to increase to $366 \mathrm{Mt}$ by year 2029 with more than $80 \%$ addition in global meat supply contributed by developing countries [3]. In last five decades, the global meat supply increased by over three times leading to animal proteins contributing upto $40 \%$ of total protein consumption at present, with similar increasing trend predicted in the near future [4]. Tonsor and Schulz [5] projected annual demand of meat will rise by a $0.24 \%$ increase in developed countries compared to the higher growth rate projected for developing countries $(0.8 \%)$. In the near future, there will be a higher demand for meat from developing countries rather than developed countries due to education, awareness towards healthy and nutritious food, rising income, industrialization, maximization of urban areas at the cost of rural regions, increasing per capita income, increasing exploration of food with greater palatability, etc. As per one prediction by Steinfeld et al. [6] meat demand will increase upto $72 \%$ by 2030 . To fulfil the food safety for projected population of 9.1 billion in 2050, animal products should be increased to 465 million tonnes $[6,7]$.

\section{PROSPECTS OF CONVENTIONAL MEAT PRODUCTION}

Any substantial increase in meat production for a growing population seems quite challenging as, at present global meat production by the conventional methods has already achieved its maximum growth potential due to constraints of natural resources. There is very little scope for further increase in meat production growth unless the industry adopts some groundbreaking innovative technologies. In addition to the availability of limited natural resources such as water, land etc., the environmental and growing awareness for animal welfare practices followed during animal rearing, and slaughter is increasingly gaining importance. Various governments have formulated legal requirements for ensuring proper animal welfare practices during animal rearing (such as farrowing pen, grazing, free-range poultry, etc.). Further, consumers are increasingly becoming more vocal about animal rights and treatments during rearing and slaughtering.

Further meat production is an inefficient way of utilizing / converting plant protein into animal protein through rearing food animals [8]. For per unit production, crops production is more efficient and requires lower natural resources as compared to meat production. Thus, meat production at the cost of staple crops is always debatable among researchers and policy makers. It has been estimated that current global meat production consumes about $70 \%$ of total freshwater and total arable land, with $20 \%$ of total electricity generated required producing fodder crops for rearing livestock. About $40 \%$ of total grains and $75 \%$ of total soya produced world-wide is used for animal rearing $[6,9,10]$. Approximately 40\% of cereals produced during 2001-2010 were used for animal feeding. Thus in the future, meat production will put pressure on already restrained natural resource as a requirement of food production needs to increase $70 \%$ by 2050 for providing food for the burgeoning population [7,11-13]. In the near future, providing healthy diet to exploding population in a sustainable and equitable manner remains the major concerns [14].

Meat production is responsible for consuming a major chunk of our natural resources such as land, water, energy etc. Various estimates prove the present meat production system as resource intensive method of converting vegetable proteins into animal proteins as 5-40 times more water is required for $1 \mathrm{~kg}$ beef production as compared $1 \mathrm{~kg}$ grains [15], utilization of about 2 lakh liter of water for $1 \mathrm{~kg}$ beef production [16], etc. Meat production is also significantly contributing to greenhouse gases (GHGs) emission such as carbon dioxide (9\%), methane (39\%), and nitrous 
oxide (65\%) of total global emission with meat and dairy animals contributing upto $14.5 \%$ of total GHG emission around the globe [3]. The main concerns of meat production were summarized as animal welfare issues during rearing and slaughtering of animals, environmental issues (such as deforestation, environmental pollution), and public health concerns (cardiovascular diseases, obesity, food borne outbreaks) [8]. The regular intake of red meat (120 g/day) and processed meat (30 g/ day) reported to increase risk of cardiovascular diseases, colorectal cancers [17].

The scientific community has raised their concerns towards overconsumption of meat in developed countries and advocating for its immediate reduction to mitigate the adverse effect on natural resources and environment [18]. The non-judicious use of antibiotics in agriculture resulted in development of antibiotic resistant bacterial strains and posed serious public health concerns. With global warming phenomenon significantly impacted agriculture production, and rising sea levels, climate changes, strained water resources have limited the scope of additional food production by agriculture in future for additional population [19]. It has been observed that a $20 \%$ reduction in meat consumption in USA would result in reduce GHG emission by $100 \mathrm{MMt}$ per year [20]. A decreasing trend of meat consumption has been noticed in developed countries due to food safety, health issues, and sustainability [21].

The application of modern technologies and management system is known to have $20 \%$ efficacy. Thus, it becomes imperative to search some novel and sustainable source of animal protein production to cater the population and to ensure food security [22,23]. On the other side, reducing consumption to a significant level seems quite challenging due to nutritive value and unique place of meat in human food basket and integral part of various traditions and socio-cultural aspects in society. In addition to being a non-sustainable production system, increasing preference of vegetarianism and vegan diets forced the policy makers, academicians, and researchers to search a sustainable method of meat production such as meat analogs or in-vitro meat / lab meat / clean meat etc. Countries such as China, India, and USA have shown growing interest and consumer acceptance towards various meat alternatives with maintaining organoleptic and nutritional quality similar to meat [24].

\section{IN-VITRO MEAT}

\section{In-vitro meat- A future meat}

The in-vitro meat is a new concept in food biotechnology comprising field of tissue engineering and cellular agriculture. Under this, edible biomass is produced by in-vitro culture of stem cells harvested from the muscle of live animals [25]. Stephens et al [26] defined it as set of technologies used to produce a typical product obtained from livestock farming by applying cell culturing technology with very little or no animal involvement. Production of meat through cell culturing is an immerging technology which has attracted the attention of researchers and academician worldwide due to its potential to supply high-quality animal protein at a relatively very low ecological footprint [27] as well as a potential alternative to conventional animal rearing and meat production system to a great extent [28]. The in-vitro meat is a meat analog produced by using cell culture. The skeletal muscle derived cells are harvested from the animal through muscle biopsy and slaughtered animals [29].

With the limited natural resources (such as land, water, energy) and burgeoning population, it is very difficult to meet the increasing demand for meat by the conventional method of meat production comprising animal rearing and slaughtering operations. The in-vitro meat production, if applied on an industrial scale with suitable technological interventions, has the potential to fulfill the requirement of animal protein to the world population in the future, and will ensure 
food security (food accessibility and food availability), improving human health in a sustainable manner [30]. The global consultancy firm AT Kearney predicted that by 2040, 60\% of global meat requirement will be fulfilled by non-conventional production methods such as in-vitro meat (35\%) or plant based analogs (25\%), due to high environmental impact and animal welfare issues associated with conventional meat production [31].

\section{In-vitro meat-As future of source of animal protein}

In some media and public debates, the meat derived from cell culturing is termed as synthetic meat, lab meat, cell-based meat, factory grown meat, Frankenstein meat or artificial meat [32,33]. During its initial developmental stage, the term in-vitro meat or cultured meat was commonly used with later one was preferred by some researchers due to the process of culturing the tissues in production of this new and innovative meat source. The term clean meat is also increasingly used from 2015 onwards in various communications. It seems more positive and appropriate to consumers than the term cultured meat [34] due to sustainability, slaughter-free and well controlled sanitation at the time of production as compared to traditional meat.

This novel product is also termed as artificial muscle proteins to differentiate it from conventional meat produced by slaughtering animals [35]. In 1931, Winston Churchill predicted production of meat in the future without the slaughter of animals by using cell culture in future his essay "Fifty Years Hence" in the Strand Magazine [36]. In 1912, Alex Carrel has successfully maintained the embryonic chicken cardiac culture for up to 34 years [37]. The first patent for industrial production of in-vitro meat for human and animal consumption was granted to Willem Frederik Van Eelen in 1999 [38]. In 2002, National Aeronautics and Space Administration (NASA) scientists successfully cultured muscle tissue from common goldfish [39]. With the support of various government and non-governmental agencies, several research grants were sanctioned, and start-ups / institutions were set up for technological innovations, feasibility to produce in-vitro meat on industrial scale at comparative prices, development of various prototypes for development and popularize this novel technology. Notably the first three research projects were awarded by Dutch government in 2005 for developing algae-based culture media [40], feasibility of culturing embryonic and stem cells [41] and stimulation of muscle cell growth by applying various chemical or electronic stimulations [42]. Various milestones in the development of in-vitro meat are presented in Table 1.

\section{In-vitro meat-Present status}

In 2013, Mark Post from Maastrich University, Netherland developed first cultured meat by culturing bovine skeletal muscle cells [26] and launched cell cultured based meat burger for sensory evaluation in a press conference in London in August 2013 [43]. New Harvest, Memphis Meats, JUST, Modern Meadow, Aleph Farms, Mosa Meat and Meatable are some important start-ups working in this ambitious venture along with research institutions. At present, these institutions can produce in-vitro meat at laboratory scale but exorbitant production costs prove major hurdle in their commercialization and popularization. Besides governmental and private agencies, several non-profit organizations such as Peoples for Ethical Treatment of Animals (PETA), Good Food Institute, Compassion USA, etc. are playing major role in supporting the development of clean meat by assisting research and development in this sector.

At present, approximately 32 start-ups / companies are continuously searching for better technological inventions to produce cultured meat on an industrial scale and popularize it. A large number of these companies are focussing on cultured beef (25\%) followed by poultry (22\%), pork and seafood (19\% each) and exotic meat (15\%), with 40\% companies based in North America followed by Asia (31\%) and Europe (25\%). Two companies are exploring mouse meat 
Table 1. Important Milestones in history of in-vitro meat

\begin{tabular}{|c|c|c|}
\hline Phase & Year & Milestones \\
\hline Origin of the idea & 1912 & $\begin{array}{l}\text { Development and maintenance of embryonic chicken heart tissue culture from } 1912 \text { to } 1946 \text { by Alexis Carrel } \\
(1912-1946)\end{array}$ \\
\hline \multirow[t]{7}{*}{ Fictionalization } & 1927 & Beef steak in Lab by JBS Haldane in his essay 'Future of Biology, \\
\hline & 1931 & Frederick Edwin Smith and Winston Churchill anticipated in-vitro meat \\
\hline & 1932 & Publication of 'Thoughts and Adventures' book including Winston Churchill famous essay 'Fifty Year Hence' \\
\hline & 1943 & French science fiction author Rene Barjavel also described the cultured meat in his novel 'Ravage' \\
\hline & 1952 & Description of Vat Grown Meat in novel 'The Sapce Merchant' by F. Pohl and C. Kornbluth \\
\hline & 1967 & Translation of Ravage novel as Ashes, Ashes' \\
\hline & 1971 & Article on Growth of Smooth muscle in culture and formation of elastic fibre by Russel Ross \\
\hline \multirow{7}{*}{$\begin{array}{l}\text { Tangible realization } \\
\text { of the idea }\end{array}$} & 1995 & Approval by in-vitro production by USDA \\
\hline & 1996 & Creation of first tissue by Oron Catts and Lonat Zurr under Tissue Culture and Art Project \\
\hline & 1997 & Lab grown fish muscle as space food by Borris Benjaminson \\
\hline & 1998-1999 & $\begin{array}{l}\text { Filing and later grant of first patent on 'Method of Producing Tissue Engineered Meat for Consumption' to Willem } \\
\text { Frederik Van Eelen }\end{array}$ \\
\hline & 1999 & $\begin{array}{l}\text { Filing of patent for 'Industrial Scale Production of Meat from in-vitro cell culture' by Van Eelen, Van Kooten, and } \\
\text { Wiete Westerhof }\end{array}$ \\
\hline & 2002 & $\begin{array}{l}\text { Cultivation of dorsal abdominal skeletal muscle mass of Carassius (Gold fish) in media containing fetal bovine } \\
\text { serum substitutes and later tested for organoleptic attributes by breading and fat frying }\end{array}$ \\
\hline & & Frog steak developed with frog skeletal muscle cells over biopolymer \\
\hline \multirow{10}{*}{$\begin{array}{l}\text { Refining } \\
\text { technology for } \\
\text { mass production }\end{array}$} & 2004 & Formation of in-vitro Meat Alliance for sustainable meat production \\
\hline & 2004-till date & $\begin{array}{l}\text { Setting up of various start-ups (especially after 2013) and increasing funding from various government and } \\
\text { environmental groups }\end{array}$ \\
\hline & 2005 & Journal of Tissue Engineering published paper on in-vitro-cultured meat production \\
\hline & 2007 & Formation of in-vitro meat consortium alliance by environment conscious scientist \\
\hline & 2008 & $\begin{array}{l}\text { Announcement of } 1 \text { million USD prize by People for the Ethical Treatment of Animals (PeTA) for the first com- } \\
\text { mercially viable in-vitro chicken meat nuggets at Ist in-vitro meat symposium }\end{array}$ \\
\hline & & Organization of first international symposium on in-vitro meat by Norwegian Food Research Institute \\
\hline & 2011 & Advocating term Cultured meat in place of in-vitro meat by European Science Foundation \\
\hline & 2013 & $\begin{array}{l}\text { Production, tasting and patent of world's first cultured meat-based beef burger in } 2013 \text { by Professor Mark Post, } \\
\text { a Dutch scientist }\end{array}$ \\
\hline & 2014 & Publication of in-vitro Meat Cookbook detailing 45 different recipes \\
\hline & 2019 & Good Food Institute USA funded 6 projects with 2,50,000 USD each for research on lab grown meat \\
\hline
\end{tabular}

Sources: $[32,36-39,78,116,160,161]$.

as alternative pet food, and another two companies are working on kangaroo and horse meat [44]. These companies are working on business-to-consumer (B2C) model mostly, but now some companies are set up on business-to-business (B2B) model for ensuring an adequate supply of necessary inputs such as hormones, growth regulators, scaffolds, culture media, cell lines, fats, etc. for companies working on cultured meat. Recently in December, 2020, in a historical breakthrough, US startup Eat Just has launched chicken bites / chicken nuggets made by using cultured meat grown in the bioreactor (capacity 1,200 liter, plant based nutrient supply using fetal bovine serum as a growth medium, which was removed before consumption) as an ingredient in place of meat (good meat cultured chicken) in Singapore at 1,880 restaurant chain after getting approval from Singapore Food Agency. The company is selling it at the competitive price of $\$ 23[31,45]$. Ivy Fram Technologies, established with Oxford University's support, expects to get approval and start selling cultured pork in the UK by 2023. The company aims to produce 12,000 tonnes of pork a year, equivalent to meat obtained by the slaughter of 170,000 pigs [46]. The major start-ups in the field of in-vitro meat are present in the Table 2. 
Table 2. Major start-ups in field of in-vitro meat

\begin{tabular}{|c|c|c|c|}
\hline Year $^{1)}$ & Country & Name of company and country & Products \\
\hline \multirow[t]{2}{*}{2013} & Netherland & Mosa meat & Beef burger of the future \\
\hline & USA & Modern meadow & $\begin{array}{l}\text { Edible dehydrated meat steak chip made of cultured meat com- } \\
\text { bined with a hydrogel }\end{array}$ \\
\hline 2016 & USA & Memphis meats & Beef fajita, meatball, duck, and chicken \\
\hline \multirow[t]{3}{*}{2017} & USA & Memphis meats & Chicken tender \\
\hline & & JUST (previously known as Hampton Creek) & Chicken nuggets \\
\hline & Israel & Aleph farms/ Meat growers & Cultured steaks using proprietary 3-D technology \\
\hline \multirow[t]{2}{*}{2018} & Israel & SuperMeat & Meal-ready chicken cultured meat \\
\hline & USA & Hampton creek food & Cultured meat and seafood \\
\hline \multirow[t]{3}{*}{2019} & USA & JUST (previously known as Hampton Creek), & Chicken nuggets, clean meat products \\
\hline & Israel & Future Meat Technologies & Shawarma, planned to reduce the cost to $\$ 2.30$ a pound by 2020 \\
\hline & USA & New age meats & Pork sausage \\
\hline \multirow[t]{5}{*}{2020} & Belgium & Peace of meat & Chicken meat \\
\hline & USA & JUST & Duck pâté \& chorizo \\
\hline & France & Gourmey & Foie gras \\
\hline & UK & Higher steaks & Pork belly and bacon \\
\hline & Neatherland & Meatable & Porcine and bovine induced pluripotent stem cells (iPSCs) \\
\hline 2021 & Israel & MeaTech 3D & $\begin{array}{l}\text { First cultivated meat company listed on the US stock exchange, } \\
\text { DNA for poultry product preparation }\end{array}$ \\
\hline
\end{tabular}

${ }^{1)}$ Year of important announcement or achievement.

Sources: [26,44,83].

\section{IN-VITRO MEAT VS CONVENTIONAL MEAT}

The production of in-vitro / cultured meat has several unique advantages as compared to the traditional meat production system and has been widely acclaimed as future of meat production or animal protein. Under this novel methods, embryonic or stem cells are cultured and converted into meat tissues without slaughtering of animals (slaughter-free meat) using cell agriculture or food biotechnology. In-vitro method recognized as efficient, environmental friendly, better ensuring public safety and nutritional security, as well as ethical way of producing meat.

The main advantages of in-vitro meat production over conventional meat production could be summarized as; 1) need for maintaining a small herd of animals for supply of stem cells, 2) better compositional and structural control by proper incorporation of ingredients or cells in culture media during processing, 3) improving nutritive value, hygienic way of production without any food toxicants or pathogens, 4) potential to produce rare and exotic meat, 5) sustainable and environmental friendly production system with very less land and water requirements, 6) quick production process, 7) production of principal products with minimum by-products and most energy diverted towards production of meat, 8) production of quality meat without affecting by extraneous factors as stress in conventional method, 9) suitable option for space and unconventional places, 10) no religious taboos / issues except the initials cells collections from cells from animals, 11) more acceptability towards this novel food by vegetarians / vegan who abstain meat due to ethical / animal welfare reasons, etc. In-vitro meat production has been credited to have low carbon 
and water footprint. As such in-vitro meat production at commercial scale would ensure slaughterfree, animal-free meat production with saving on 50\% in energy, $99 \%$ in land use and $80 \%-95 \%$ water intake and 75\%-95\% lower emission of GHGs [40].

Tuomisto et al. [40] and Bartholet [47] observed huge saving on various inputs (82\%-96\% saving on water, $98 \%-99 \%$ less land) by using cyanobacteria as a source of nutrients in addition to huge reduction (upto 78\%-96\%) GHGs emission. The savings on input varies with the type of meat under consideration, such as higher in poultry and pork than beef $[25,40]$. The large scale adoption of in-vitro meat in Europe has been projected to decrease GHGs emission by 2 folds. Most of the land at present under crop or fodder production reverting back to wild, leading to reforestation resulting in improving ecological balance, increasing availability of biofuels, saving natural resources for future, etc. [48]. Harvesting a large number of stem cells from small group of high-yielding animals would increase the profitability and returns per animal and prove a better alternative to intensive farming systems. It will open a new arena for the production of meat of rare and exotic species. This production method will shift the focus from high-yielding and genetically modified animals to conventional livestock breeds that are better adapted to a particular climate and sustain at low inputs and extensive systems, and helps in preserving biodiversity [26]. The salient merits of in-vitro meat production over conventional meat production have been summarized in Table 3.

\section{THE TECHNOLOGY OF IN-VITRO MEAT PRODUCTION}

There are several technologies / processes are available describing the production of in-vitro meat (Fig. 1), but, some of these methods are under the stage of commercialization, while others are still under the developmental phase / conceptualization stage or feasible on a laboratory scale only. Cultured meat production is done by two methods viz. self-organizing (use of explants harvested from animals to produce structured meat as self-organizing constructs) and scaffolding (growing and differentiating myoblasts in the scaffold in growth media leading to unstructured and soft tissue) [49]. Under scaffold-based process, the embryonic myoblast or stem cells harvested from live animals are multiplied and fixed to substrate or scaffold made up of collagen or micro-carrier beads in growth media of bioreactor. Under the self-organizing method, explant harvested from donor animals is proliferated in culture media leading to the formation of tissues resembling conventional meat in structure, composition, and organoleptic attributes due to presence of additional adipose tissue, circulatory system, etc. in developed muscle tissue [30]. However incidences of necrosis have been reported in cultured cells present at $0.5 \mathrm{~mm}$ or more distance from nutrients due to poor nutrients supply [50].

\section{Inputs of in-vitro meat}

For a cultured meat assembly (CMA), tissues specific cells (such as muscle, adipocytes, circulatory, chondrocytes, etc.), culture media, and bioreactor form an integral part [51]. Various cells possessing property to proliferate and retain their ability to remain undifferentiated forms such as stem cells, satellite cells and adipose tissue stem cells are used for the production of cultured meat [52]. Stem cells derived from matured cells responsible for regeneration and repair of tissues can also be used for cultured meat but these cells are more prone for senescence upon growing in-vitro [53,54]. Presently, satellites cells are commonly used, and researchers stressed the search for genetically modified cells as an alternative to adult stem cells and satellite cells [49]. The telomerase genes in cells determine the cell multiplication. The suitable modifications in these genes will increase the Hayflick limit (number of times cell divide before senescence) of these cells [55]. Alternatively for 
Table 3. Various aspects of conventional meat and in-vitro meat

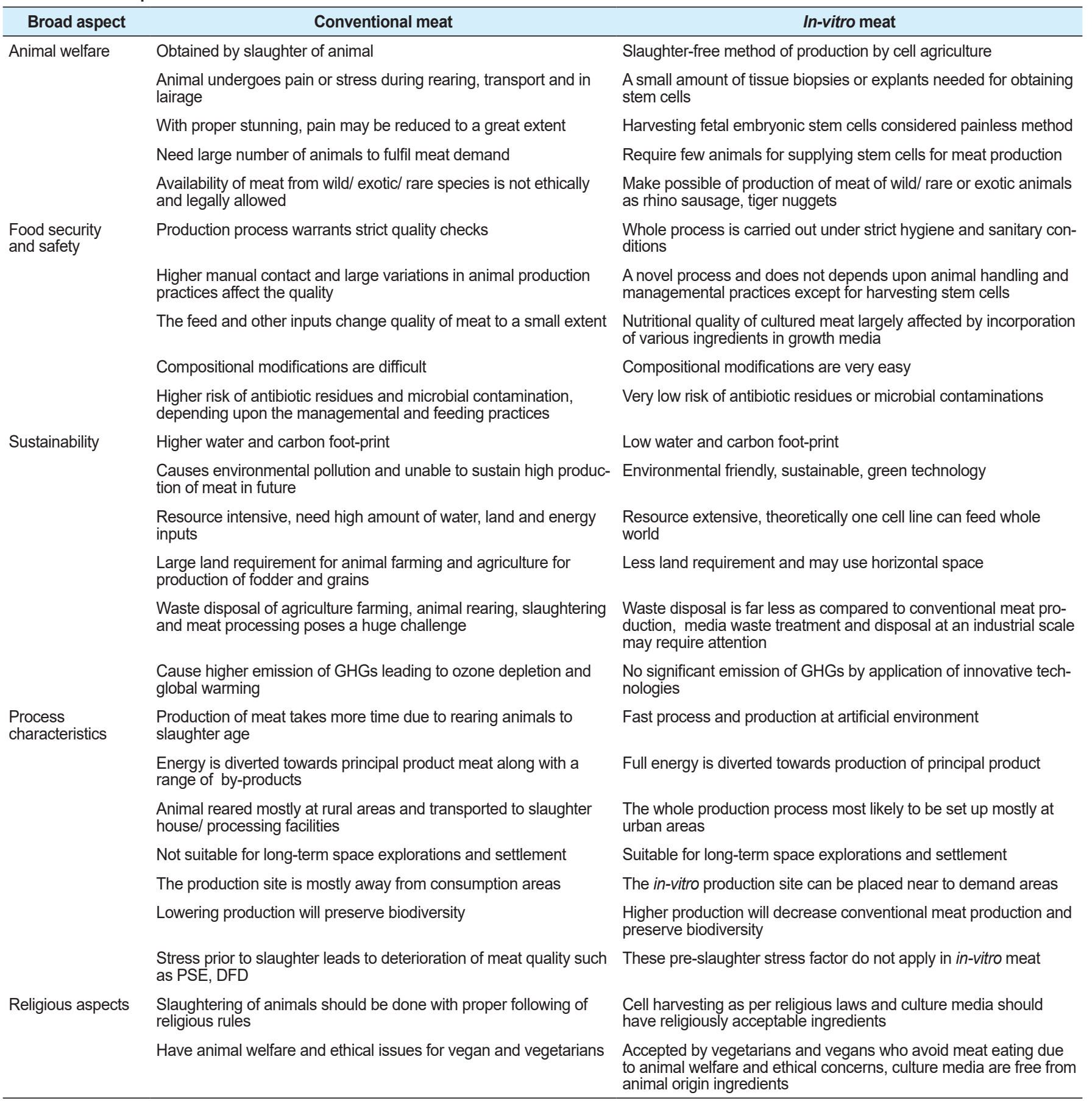

GHG, greenhouse gas; PSE, pale soft exudative; DFD, dark firm and dry.

CMA, induced pluripotent porcine stem cells by inducing embryonic gene expression may also be used in future $[56,57]$. Three dimensional (3D) scaffolding is used to prepare well-structured cultured meat such as steaks [58].

\section{Cell culture}

The cell culture comprises harvesting biopsies or explants from farm animals, separating out the stem cells, proliferating, growth and differentiation of these cells in media under specific physical 


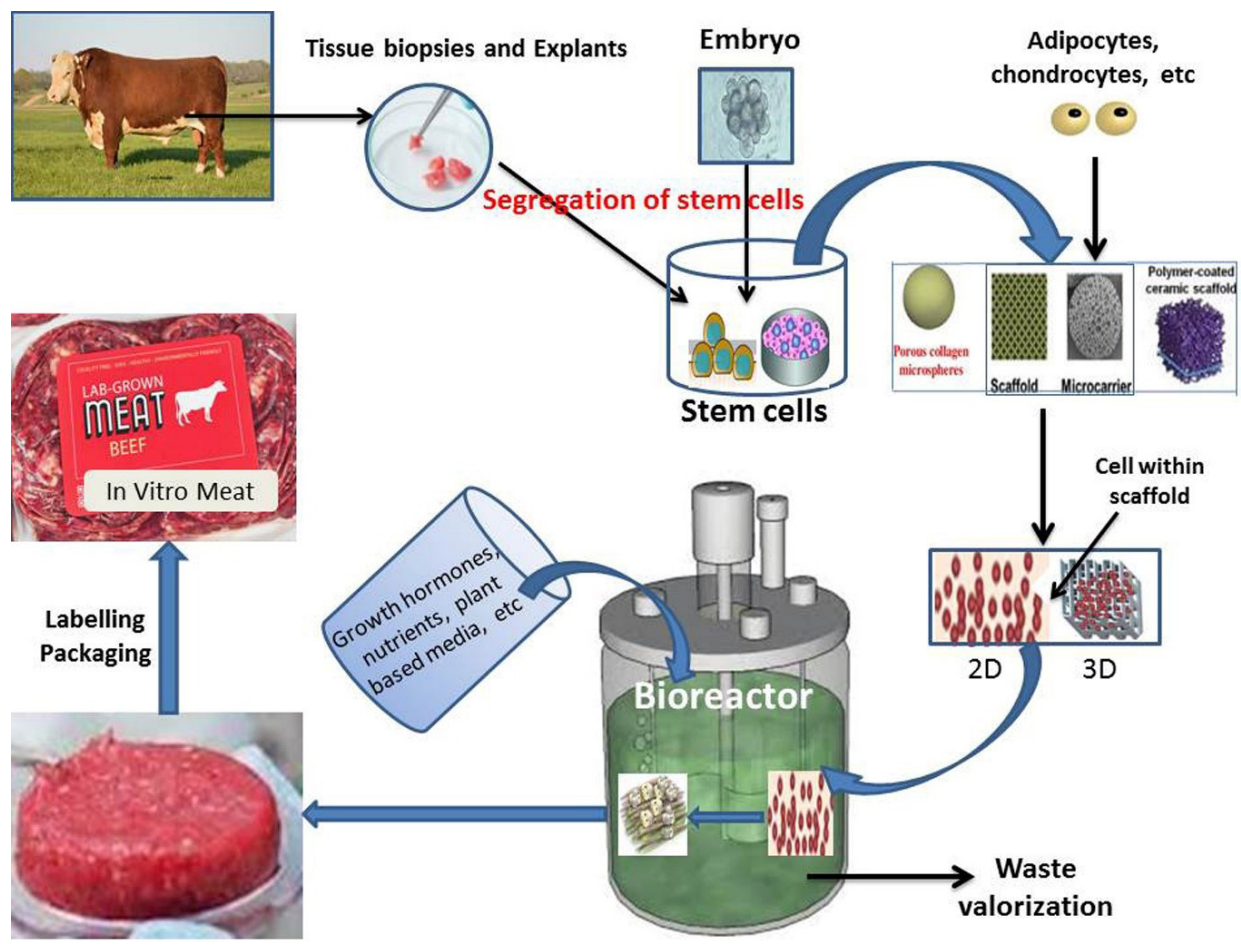

Fig. 1. Schematic view of various technological aspects of in-vitro meat production.

and chemical stimulants [23]. For cell culture, stem cells obtained from adult tissue-derived myoblasts or satellite cells are mostly utilized. A major portion of meat is formed by muscular tissue comprising skeletal muscle fibres. Muscles have regeneration power and recover from minor damage due to presence of satellite cells, types of stem cells present in skeletal muscle. These satellite cells are responsible for muscle regeneration and tissue repairs and have the inherent ability to grow and differentiate in any cells / tissue depending upon the stimulants. These cells proliferate and differentiate into the desired muscle cells while maintaining their constant number in muscle owing to their self-renewal ability [59]. Under normal conditions, these cells remain in quiescent / inactive stage regulated with negative cell cycle by halting the cell cycle, various growth regulators, up-regulated notch signalling, and expression of tumour genes as retinoblastoma $(\mathrm{Rb}), \mathrm{P}^{53}, \mathrm{P}^{21}$ [60]. These cells are activated by various extrinsic and intrinsic factors such as muscle injury. Notch downregulation of cell differentiation / development leads to myogenic differentiation under various factors expressed upon activated satellite cells such as myogenic factor 5, myogenic determination, myogenin $[60,61]$.

These cells are grown in media on a scaffold in a bioreactor and they fuse together under specific environmental stimulations and differentiate into myoblasts which further fuse to form myotubes, which differentiate into myofibres under different environmental stimulations [27]. These myofibers are taken out from scaffold and processed for development of various meat products. There may be variations in design of scaffolds. Edelman et al. [55] proposed use of collagen beads as scaffolds in the bioreactor for production of myocytes. This method of production of in-vitro meat has some issues such as by using this scaffold method, only a thin layer of myocytes (100 to $200 \mu \mathrm{m}$ ) can be harvested due to limited diffusion of cells on scaffold due to static conditions needed for cell culturing [62]. 


\section{Tissue culture}

Tissue culturing is used for preparation of high volume of structured meat. Fish fillets were obtained by increasing gold fish explants area within a week time [39]. These fillets were also ranked high on sensory attributes. The culture medium should imitate the in-vivo conditions to get cultured tissue similar to their origin tissue. This imitation has been a limitation and may lead to necrosis and atrophy in developed cells after some time due to lack of nutrients, resulting in the detachment of these cells from the surface [63]. To overcome these practical difficulties in tissue culturing, it was recommended to apply tissue engineering techniques to grow cells on networks of edible porous material. That porous material / polymer will act as a blood vascular system and improve medium perfusion to growing myoblasts and other cells [64]. There are two methodologies to produce in-vitro meat viz. self-organizing (by producing highly structured meat from explant and continuous removal of these cells) and scaffolding where cells are grown, proliferated, and differentiated onto scaffold or microbeads in growth medium [65].

The scientific community had advocated the possibility of preparation of lab meat similar to conventional meat by using different tissue in appropriate amounts by using cultured myoblasts with other cell types [23,66]. Similarly Wolfson [67] proposed formation of edible porous polymer comprising an artificial circulatory system. However, the difficulties during cell diffusion, culturing prove major hindrance during its commercialization.

\section{Organ printing and nanotechnology}

Organ printing and nanotechnology is widely acclaimed as future technology for preparation of cultured meat, structurally and functionally similar to conventional meat. It comprises 3D bioprinting or four dimensional (4D) bioprinting technologies making it possible to produce tissues resembling conventional meat in anatomical, compositional, functional, and structural attributes [68]. The 3D printing / additive manufacturing (AM) / rapid prototyping facilitate novel products development from digital Computer-Aided Design (CAD) software by well-defined sequential process. Under $3 \mathrm{D}$ printing, $\mathrm{CAD}$ model of configuration is prepared followed by converting it into standard triangular language (STL) format [69]. It is possible to prepare organs and tissues marked resemblance with conventional meat by using this method and have huge market potential. Under $4 \mathrm{D}$ printing, one more dimension of transformation over a period of time is added to $3 \mathrm{D}$ printing. This method is mostly used for production of regenerative tissues such as muscle, cardiovascular tissues or bone [70]. Recently there is marked reduction in cost of 3D printers and same trend is expected to remain in future. At present, laser printing (costly but highest resolution / precision), extrusion printing (slower, economical, continuous release of material), inkjet printer (cheaper, small droplet size, applied to low viscosity materials as surface energy and rheological attributes), powder binding printing (PBP), selective laser sintering (SLS) and hydrogel forming extrusion (HFE) are the major technologies used for $3 \mathrm{D}$ printing. By using this technology, it is possible to develop unique food products with proper nutritional value, intricate shapes, colors, and unique textures by applying food ingredients and suitable printing technologies [69,71]. In the production of invitro meat, these technologies are still in conceptualization and laboratory scale, and there is need to major technological breakthrough in controlled process of cell distribution, high cell deposition, innervation and circulatory system within intricate 3D tissues [72].

Tissue engineering deals with cell culturing on adhesive surface made up by bio-mimicked scaffold leading to combining of cells and various biomaterials. Kingsley et al. [73] observed the development of circulatory system, physical strength, anatomical structure, proper nutritional value and presence of functional cells as major issues to be resolved for adoption of tissue engineering technology on industrial scale. The process of combining of cells and biomaterials in scaffold can 
be further divided into two types viz. top-down (lack of extracellular matrix due to less control over the distribution of cells leading to poor functioning of tissues) and bottom-up (forming tissues brick by brick by proper precision through nano- and microtechnologies) [72,74]. Nanotechnology deals with particles at nano size i.e. less than $100 \mathrm{~nm}$ and it has several inherent advantages in tissue engineering and development of various tissues or organs by using novel technologies of softlithography and self-assembly facilitating suitable environment for growth of cells [75,76].

\section{Culture media}

Culture media provides a proper and continuous supply of nutrient for proliferating cells. Culture media mostly prepared from fetal or newborn or adult bovine source [77]. These animal sources derived media are costly, inconsistent composition depending upon in-vivo source, risk of pathogens, etc. making it unsuitable for production at industrial scale. Moreover, the media obtained from animal sources as fetal bovine serum has ethical concerns. It makes in-vitro meat obtained from such media unfit for consumption by vegan or vegetarian population or specific religious issue. The serum-free media made up of plant or synthetic compounds facilitating similar growth potential as serum media were developed, such as amino acid-rich plant based media from maitake mushroom extract was reported optimum for growth and surface area expansion for fish explants [39]. Similarly Ultrasore $G$ is a serum free media developed as an alternative to serumbased media, containing all necessary nutrients required for cell proliferation such as vitamins, growth hormones and regulators, binding factors, trace minerals, etc. Datar and Betti [65] observed that such growth media with plant proteins might cause allergic reactions in sensitive consumers. Different culture media have been developed for proliferation and differentiation of various animal cells. These growth media have developed at small scales with their manufacturing process is copyright / patented and very difficult to assess their cost of production at commercial scale.

Cyanobacteria is widely considered as a potential source of energy and supplements for cell growth. These can be cultured very easily and contain good protein source (70\% of dry matter) [78]. Proper understanding of metabolic modelling and flux balance analysis to better understanding the optimal nutrients required to grow cell in-vitro is very important [28]. Usually $10 \%-20 \%$ of growth media and $0.5 \%-2 \%$ fetal calf or horse serum or chicken embryo extract is added in culture media intended for cultured meat production, which support in the effective cells differentiation $[79,80]$. Serum-free media with greater growth potential of cell culturing had been developed by incorporating supplementary proteins, and development of novel media such as AIM-V, Sericin and Ultroser G [81]. AIM-V media was noted to increase active tension during cell differentiation. The growing cells require a wide range of growth factors, hormones, vitamins, amino acids, fatty acids, trace elements, L-glutamine, antioxidants (glutathione, 2-mercaptoethanol), and extracellular vesicles for cell growth varies with types of cells and their origin. The cell culture media should be added with various antibiotics (such as amphotericin, fungizone, gentamicin, penicillin, streptomycin, etc.) or antimitotics to control microbial contamination, dexamethasone, cell signaling molecules (heparin sulfate, hepatocyte growth factor, insulin-like growth factors, interleukin, betacatenin signaling inhibitor, etc.) $[26,82,83]$. It is desirable to avoid using these antimicrobial agents to avoid side effects such as hypersensitivity, reproductive disorders, gastrointestinal disorders, and emerging antibiotic resistance in microorganisms [84]. The proper care should be taken to prevent contamination during cell culturing such as proper identification of Mycoplasma by detection kits, utilization of natural bioactive compounds exerting antimicrobial effect [83].

\section{Scaffolding / cell substrate}

It is very difficult to grow cells in media and get tissue like structured without appropriate provision 
of scaffold, providing suitable niche for optimum cell growth similar to extracellular matrix invivo. A solid surface is required for growing myoblast for attachment and maximizing their surface. Scaffold facilitates anchorage to muscle cells and provide sufficient physical strength. During in-vitro meat production, the scaffold is required to attach and efficient utilization of available nutrients $[85,86]$. At present, mostly hydrogels with porous structure are utilized as base material for cell scaffolding as it ensures proper access of nutrient and oxygen to cells [87]. Myoblast cells need a solid framework or surface or scaffold mostly collagen-based for proliferation and differentiation [88].

An ideal scaffold should be sourced from non-animal source (suitable collagen alternatives) and have large surface area for proper growth and attachment of cells, flexible with tissue like stiffness for proper growth of myotubes, proper medium diffusion and ability to separate easily from cultured meat $[28,65,89]$. The use various edible and inedible polymers such as collagen, cellulose, synthetic polymers as poly (L)-lactic acid as base materials for preparation of scaffold materials has been advocated [30]. Additionally, cost effective scaffolds were developed from textured soy protein for production of cultured meat. Making a gel-like base material similar to original tissues, decellularized extracellular matrix bioinks incorporated with various tissue-specific growth factors, adhesive proteins, etc. are introduced for better growth and differentiation of cells in tissue engineering $[90,91]$.

Scaffold having striated texture has been reported to facilitate formation of myotube owing to its resemblance to structure of muscle [92]. The development of an edible scaffold will make the process faster and avoid removing cultured tissues from scaffold and potential damage during this process. The Researchers used materials derived from an animal source (such as gelatin) and plant sources for developing edible scaffold. A gelatin based fibrous scaffold by using rotatory jet spinning technology for cell culturing of bovine and rabbit originated cells has been developed [93]. Micromolding of thin hydrogel films has also been also used to produce scaffold with groove texture [94]. Plant materials such as textured soy protein have been utilized to prepare plantbased scaffold due to their porous structure, which promotes proliferation of bovine myotubules [85]. These scaffold formation need prior chemical functioning or pre-treatment with extracellular matrix protein to support adhesion and increasing functionality similar to animal-based scaffolds [95]. For production of thicker cuts of cultured meat, increasing vascularization by bioengineering into cultured meat was done to maintain the proper supply of nutrient to cells in media. Based on projections on glucose concentration, its diffusion and consumption by mammalian cells, it is feasible to get maximum viable thickness of $400-1,400 \mu \mathrm{m}$ for $100 \mathrm{~g}$ meat containing approximately $3 \times 10^{10}$ cells [96].

\section{Removal of cells sheet}

The removal of cells sheet or tissue from scaffold is very important, and it can be either by use of enzymatic methods or by applying mechanical force [97]. These methods are destructive methods and potentially damage the sheet. For removing cultured cell sheet intact, the use of nondestructive methods by detaching culture as a confluent sheet from non-adhesive surface due to biodegradation of selective attachment protein laminin [98] or utilizing thermos-responsive coating converting hydrophilic from hydrophobic upon decreasing temperature [99]. Cultured muscle cells on novel decellurized plant tissue based scaffold was observed to stimulate better proliferation and differentiation as well as providing better myotube alignment [100].

\section{Co-culture}

Co-culture refers to growing two or more different types of cells simultaneously in a single shared 
medium, where physical contacts among different cells directly impact the cellular function. Thus to prevent the direct interaction between different cells, one type of cells are grown in a permeable membrane, suspended in medium having a different type of cells [101]. Co-culture is similar to in-vivo environment. 2D single type cell culture (monoculture) has only single types of cells and does not involve cellular interactions, whereas 3D co-culture involves more than one type of cells. Adipocytes differentiation factors play an important role in co-culture comprising adipocytes, pre-adipocytes, fibroblasts, and endothelial cells, where each cell impacted other types of cells. Growth factor, insulin like growth factor (IGF-1) and insulin-like growth factor-binding proteins (IGFBP) promotes pre-adipocytes to undergoe cell multiplication and differentiation. The platelet-derived growth factor and epidermal growth factor promote the multiplication of adipocytes, whereas insulin, growth hormone, IGF-1, thyroid hormones, and glucocorticoids help differentiate adipocytes into adipose tissue [101,102]. Pandurangan et al. [103] successfully cocultured myoblasts and fibroblasts cells for 24-72 h. While, co-culturing fibroblasts and myoblasts, a relatively higher growth rate of myoblasts could be achieved by inhibiting fibroblast cells [104]. Several factors affect muscle and fat, such as stress hormones (cortisol and epinephrine) [103].

\section{Oxygen carriers}

For proliferating cells, oxygen is needed for various metabolic activities and it depends upon the cell density. Lack of proper oxygen supply may affect survival of these cells leading to necrosis. Various modified form of haemoglobins and synthetic perflurochemicals have potential to carrier of oxygen in bioreactors but these compounds generation is associated with production of GHGs [105] and thus need a better sustainable alternative to these compounds in future.

\section{Bioreactor}

Bioreactors used in in-vitro meat production facilitates biological and associated biochemical reactions in a properly controlled and monitored environmental and operating conditions (such as pressure, temperature, oxygen supply, waste removal, $\mathrm{pH}$, etc.), thus ensuring a high degree of precision, reproducibility, repeatability, and automation needed for large scale operations [106]. The cell culturing should be done in a proper controlled environment under strict hygienic and sanitary conditions. For production of cultured meat at commercial scale, sufficient size and closed area is a prime requirement for proper growth and differentiation of the large volume of cells needed for the commercialization of this technology [27,49]. There are basically 4 steps in production of in-vitro meat: cell proliferation, cell differentiation, product manufacture, and waste valorization [26]. The production of cultured meat requires a complex environment with optimal supply of nutrients and favourable environment. The present bioreactors could be easily scaled up to 5 litres capacity and it could be further increases upto 2,000 litres with suitable modifications / alterations [107]. The bioreactor used by US start-up Eat just to prepare chicken bites in Singapore at 1,886 restaurant was 10,000 liter capacity. The company proposed to have bioreactors of about 50,000 liter capacity for the commercialization of in-vitro meat around the globe [31].

The bioreactor provides favorable environmental conditions for the growth and differential of cells. Industrial bioreactors for in-vitro meat production should be designed in such a way that facilitates cell suspension in a near-continuous medium, maintain lower fluid shear force, proper growth of cells similar to native tissue, facilitates easy separation of suspended tissues, and should provide an environment for proper growth and differentiation of cells leading to increased yield [108]. The industrial bioreactors should have the same functionality as that of lab scale bioreactors for the production of in-vitro meat in laboratories $[30,65,108]$. In rotating wall vessel bioreactors, the medium flows in a laminar flow with the help of a rotating wall at the designated speed that 
maintains the proper balance between centrifugal force, gravitational force, and drag force. This balance between various forces is desired for proper diffusion at improved mass transfer rate at reduced shear stress to the growing cells, which are submerged in the medium in free flowing threedimensional states [106]. For scaffold based cell culturing technology, direct diffusion bioreactors are recommended due to the proper flow of growth media and gaseous exchange across the porous scaffolds. The proper maintenance of flow rate is very critical to ensure a high mass transfer rate and lower shear stress [109].

The vascularization of growing tissue helps in increasing mass transfer / medium perfusion. Endothelial vessel networks had been introduced by Levenberg et al. [110] by using co-culturing myoblasts on a very porous scaffold with endothelial cells and embryonic fibroblast to increase medium perfusion. For efficient production of in-vitro meat at a large scale, sufficient oxygen perfusion is required ensuring viability and proper growth of cells during cell seeding and cultivation onto a porous scaffold, and oxygen perfusion gradient determines the density of cultured tissue [111]. Oxygen carriers (such as modified haemoglobin produced from modified plants or chemically produced perfluorochemicals $[\mathrm{PFC}]$ ), are used to mimics hemoglobin of the blood to provide adequate oxygen supply to growing cells in bioreactors [105].

\section{OVERCOMING LIMITATIONS OF IN-VITRO MEAT PRODUCTION}

Although in-vitro meat technology has several potential advantages over conventional meat production systems, but it has some limitations or challenges. The current research works are mostly dedicated to making this technology more feasible, cost effective, and suitable for production at an industrial scale. The various issues in the in-vitro meat production are as follows-.

\section{Production process}

Most of the present process have poor surface to volume ratio due to culturing in flasks or petri plates where cells are placed in the bottom and getting required nutrient from media above cells, thus limiting their scale-up at an industrial level. For resolving this problem, cells are grown by suspension method by attaching to tiny beads or spheres suspended in culture media. Mesenchymal and myoblast cells were successfully grown by attaching on microbeads in 1.5 litre bioreactor or flask having provision of continuous stirring [51]. For making this process suitable for adoption by industry, various issues such as culture media, seeding density, microcarriers, medium alterations, etc. need to be addressed [112].

The produced cells should be differentiated into tissues at large scale. The whole process such as cell harvest, cell production, tissue formation should be accomplished under sterile conditions, preferably by automation so to minimize the risk of contamination during manual operation [51].

\section{Adequate supply of cells}

Cell lines with increased growth rate and differentiation produced from somatic cells by recent technological innovations such as genetically engineering, chemical induction or spontaneous mutations $[113,114]$ have the potential alternative to harvest stem cells from live animals. However these cell lines requires passaging, subculturing, proper identification and separation and issues with continuous evolution [26]. Alternatively, stem cells / pluripotent cells can be obtained from tissues from a small herd of animals reared for harvesting on a regular basis for culturing. At present satellites cells from muscle are most widely used stem cells with increasing use of mesenchymal stem cells and other multipotent cells that can grow without animal serum along a high growth rate [115]. Embryonic stem cells also proves an alternative but differentiating these cells towards 
a muscle cell lineage proves challenging. There is research and studies going on towards finding optimal cell source for in-vitro meat.

\section{Nutrient transport}

During the production of in-vitro meat, the main challenges are the requirements of a consistent supply of oxygen and nutrients to growing cells while removing wastes generated during growth, i.e. for a proper functional circulatory system similar to live animals. The present technology made it possible to produce small pieces of meat only, but producing proper muscle with a mature vascular system needs advanced bioreactors that will be available in the future by adequate research and innovations [32].

\section{Production of in-vitro meat similar to conventional meat}

The success of cultured meat depends mainly on the degree of its resemblance / imitation to conventional meat in organoleptic attributes such as flavor, appearance, color, texture, juiciness, etc. at an affordable price. It is only possible when cultured meat will have similar physiological and chemical composition to conventional meat. This has several technological challenges in the production of fully structured cultured meat production.

One major issue with prevailing methods of production of in-vitro meat are lack of some critical steps happened during conversion of muscle to meat which has major effect on organoleptic attributes of meat and meat products such as $\mathrm{pH}$ decline by postmortem glycolysis, rigor mortis, calpain activation, resolution of rigor, rigor resolution, conditioning / ageing, etc. Besides muscle fibres, conventional meat comprises various other tissues such as adipose tissue, nervous tissue, epithelial tissue and circulatory tissues in various concentrations. In cultured meat, these tissues are lacking at present and various research works are undergoing across globe to prepare cultured meat similar to conventional meat in sensory attributes, composition and texture by including various tissues by coculturing with adipocytes and other cells [116].

The presence of adipose tissue in conventional meat is responsible for colour, texture, juiciness and flavour of meat and in cultured meat, coculturing myoblast with adipose cell leads to formation of adipose tissue in cultured meat, but the higher maturation time of adipose cells ( $2-3$ months) and changing test conditions makes it quite challenging and need further testing and research. For structural and functional resemblance to meat, satellite cells are cocultured with adipocytes (for adipose tissue development), fibroblasts and chondrocytes (for connective tissue development) and endothelial cells (for development of circulatory system / vascularization) [26].

Production of typical meaty flavor in cultured meat is very difficult as such as it is a result of reactions of numerous fat and water soluble components. Appearance of lab grown meat tends to be less reddish and more yellowish or pinkish tinge due to lower myoglobin formation in cultured meat due to higher oxygen saturation [51]. Culturing under low oxygen conditions is recommended for production of high myoglobin content in proliferating cells, resulting in development of reddish colour [117]. Alternatively, heme from plant source has been incorporated during culturing for developing colour and flavour of cultured meat close to conventional meat in addition to fortifying iron [118].

The sensory attributes of a product such flavor and color plays important role in consumer acceptance. The color and flavor of cultured meat could be improved by adding heme compounds such as haemoglobin or myoglobin and incorporation of adipocytes or encapsulated lipids in media $[119,120]$. The typical flavour of meat products is resultant of several complex compounds originated during cooking such as cyclopentanone, pyrazine, furan, 2-methylpropanal, 3-methylbutanal, 2-nonenal, 2,4-decadienal, thiopenes, etc. [121]. 


\section{Sustainable culture media and cell substrate}

A proper culture media and scaffolds are needed for optimum growth of cells at economic cost, popularization, and scaling up of in-vitro meat production. The media ingredients produced from fetal calf serum (mostly used for culturing cells for pharmaceutical purpose) or horse serum, microorganisms and plants, should fulfil the requirement of growing cells. Use of 10\%-20\% supplementation of growth media with $0.5 \%-2.0 \%$ of fetal calf serum or horse serum in culture media was observed for better initial growth and differentiation [26,80]. Media should contains antibiotics, chicken embryo extract, nutrients such as fatty acids, vitamins, amino acids, minerals, metabolic regulators, and various growth factors, hormones and inhibitors in a specific proportion [82], however, the specific ingredient responsible for growth in serum are still not properly known [122]. The use of serum in culture media could be an issue in acceptance of developed meat and need to develop serum free-media for myoblast proliferation. The risk of contamination / diseases, variations in between batches and regular supply of serum based media are required for commercial production of in-vitro meat.

Better myoblast cells differentiation has been observed in scaffold obtained from the animal origin materials such as mostly collagen as it imitates their natural environment causing these cells to reside and align, compact, and form muscle fibre. Scaffolds prepared from synthetic materials from bioengineering, failed to yield satisfactory results during tissue formation and cells differentiation $[123,124]$. The incorporation of collagen during scaffold formation adds variations and is not considered as a sustainable source. There is a need to search of nontoxic, biocompatible and optimum structure strength scaffold materials that facilitates easy binding and interactions of proliferating cells to form compact tissue. Some compounds such as polymeric sugar chains have all qualities needed for scaffold formation but lacks suitable binding sites of myoblast cells [32]. Alginates, plant cellulose and chitins added with short peptides to increase binding sites were reported as suitable materials for large scale scaffold production [125]. Canavan et al. [97] explored the use of polyglycolic acid, polyurethanes and polylactic acid for scaffold preparation and observed the problem associated with removal of scaffold as removal of scaffold with the help of enzymatic action or by using mechanical force may damage the cells and scaffold.

da Silva et al. [98] explored novel 'thermal lift-off' for removing cell sheet intact by using materials that becomes hydrophilic during cooling. Further these sheets have the ability to bind with other substrates and formation of 3D product by stacking of sheets. Alternatively Lam et al. [99] postulated removal of cell sheets by selective biodegradation of protein laminin attached to non-adhesive micro-patterned surfaces. During removal of cell sheets from scaffold without any support base could cause aggregation of cells due to contractile force leading to the formation of multicellular detached spheroids, thus need to have support surface by using hydrophilic gel or membrane [99].

\section{Technological challenges during acceptances}

There is huge media coverage advocating several benefits / advantages of this technology. There had been extensive media coverage of cultured meat burger testing in London in 2013, and overstressing the acceptance among vegetarians without proper assessing the various technological challenges of its acceptance and consumer reactions. Consumer attitude and perceptions about a new product such as in-vitro meat plays a key role in its success and acceptance at industrial scale [65]. It can be modulated by increasing awareness about these novel products, depicting it similar to conventional meat and emphasizing the sustainability of vitro meat [126]. 


\section{Animal welfare and ethical issues}

Animal welfare and ethical considerations are the major force behind in-vitro meat, and thus, the harvesting process of donor cells should be painless and stress free. Culture media is based on fetal serum obtained from blood of foetuses of slaughtered pregnant cattle. Further research is needed for developing of animal-free media. In cultured meat, necrosis has been observed in case of an inadequate supply of nutrients from media. The increasing evidence about various ill effects on consumer's health upon overconsumption of processed meat may be an issue in future as in-vitro / culturing process till now only produces processed meat only [23].

This in-vitro meat production system is slaughter-free meat production. It largely frees from animal welfare issues as concerned with the modern rearing of meat animals and meat production. In the modern intensive practice of conventional meat production, there is a higher probability that these animals do not have 5 basic freedoms and are mostly treated like small production machines rather than living animals. During the whole production system of conventional meat system, animals should not be hungry and thirsty, proper comfort, should not have any pain, disease, or injury. The surroundings should not interfere the normal expression of behavior and instincts and should be free from any distress or fear. As the novel in-vitro meat production system, there is no need for rearing the meat animals on such a large scale rather than few animals needed for harvesting stem cells.

The treatment met to animals just prior to slaughter remains a burning issue in the meat industry. The most common animals well-being issues are related to conventional meat productions are rearing in congested places, improper handling, use of hormones, growth promoter, longdistance travel in improper conditions without proper ventilation, density, proper rest, feeding and watering; insufficient rest, and poor housing conditions at lairage, bruises and injuries, improper ramp and pens, rough handling, improper or inefficient stunning, slaughter without stunning, etc. are major issues in animal welfare during conventional meat production. The animals should be properly rested, fed, watered in lairage, and should be properly stunned to reduce pain to minimum level. Further, mishandling of animals and slaughtering in a state of undue pain and stress leads to poor quality of meat (such as pale soft exudative meat, dark firm dry meat, two tonings, etc.), fetching less price in the market and even rejection by consumers, leading to heavy economic loss to the meat industry. Nowadays, peoples are very concerned about the conditions and treatments met to animals during slaughter, and animal welfare issues are gaining importance and have a role in consumers purchase and consumption of meat. The in-vitro meat production system will be helpful in preserving genetic resources, especially in terms of saving genetic resources in the form of saving unproductive animals. The in-vitro meat production system has moral and technological advantages as being free from the most challenges related to the conventional meat production system; hence have the potential to be a suitable option for consumers.

\section{Cost of production}

As in-vitro meat production process is less efficient than plant itself, some scientists / policy makers doubt the justification of moving from plant to in-vitro meat at the cost of non-availability of food for a larger section of society in the future. Further, it may increase dependency on certain suppliers at the cost of the availability of food locally from agriculture. At present, the higher production cost of in-vitro meat proves a major hurdle in the acceptance of this novel meat. Schwartz [127] noted the significant reduction in production cost of one beef burger from USD 325,000 to USD 11.36, but still higher than the prevailing price of beef burger prepared from conventional meat. However, in a survey by EKOS on the consumer's acceptance of conventional beef burger, in-vitro meat burger and meat analog burger in a hypothetical situation of similar price and observed that a majority 
of consumers still prefers for conventional meat followed by plant based burger and in-vitro meat burger [128]. Weele and Tramper [129] projected the need to grow 1,023 cells to get 1,011 kg meat per year to completely replace conventional meat to in-vitro meat for a population of 10 billion by 2050. This will lead to several practical difficulties and technological challenges such as establishing ultra-modern facilities, well-trained staff, and high cost of various inputs such as growth media, salaries of trained staff, etc.

\section{CONSUMER ACCEPTANCE}

Consumer preferences and choices have direct influence on meat production practices (Fig. 2); eating quality being the major driver, but at present consumers are also concerned with processing conditions, traceability, animal and environmental effect of production [130]. Changing ones eating habits is very challenging (food neophobia) and several incidences have been reported where individuals even resist reducing meat eating in context of increasing risk for various cardiovascular disease [131] or type 2 diabetes mainly due to socio-cultural habits. It could be forecasted that a small section of meat eating consumers would change to vegan or vegetarian diet under the influence of motivation by various environmental, ethical, food safety and economic reasons but encouraging significant numbers of peoples to change their food habits or significant reduction in meat consumption need a holistic approach and better understanding acceptance dynamics of developed novel product [21,95].

Like other novel food, consumer acceptability and future survival of cultured meat may face several social and technological challenges such as cost of production, perceptions about products, sustainability, organoleptic attributes, etc. Certain technical, economic and social constraints (higher



Fig. 2. Dynamics of consumer perception. Adapted from Umaraw \& Verma with permission of Fundación Dialnet [130]. 
resistant in conservative section) and uncertainty about consumer acceptance of new products should be properly understood before exploring its acceptance by consumers [132]. Presently, most of studies undertaken / published / advertised in print media regarding consumer acceptance and future of in-vitro meat are done by proponents of in-vitro meat, emphasising mainly its merits, process, animal welfare, sustainability and history [133]. Still, consumer acceptance and technological issues are not appropriately understood, and there is need to involve and aware consumers at early developmental stage of this novel food product. There were instances that several people in developed countries did not accept the new and innovative technologies due to lack of proper information as it was propagated at the time of development such as nanotechnology [134]. The consumer's reaction and attitude formation towards in-vitro meat amongst consumers from Belgium, Portugal and United Kingdom was studied noted that initial reaction of unnaturalness and disgust feelings as major bottlenecks in acceptance of this product by consumers [21]. However consumers acknowledged fewer direct benefits but were ready to accept it owing to sustainability and global meat supply, while uncertain about the food safety and impact on society, especially loss of traditions of meat eating, livelihood loss, religious believes, etc. It is recommended to give more emphasis on describing the product attributes and its inherent advantages rather than production process as the way of product description has significant effect on consumer acceptance towards invitro meat [135]. The use of small scale production methods having well identified / known source of donor animals had been suggested to reduce feelings of alienation and unnaturalness associated with in-vitro meat [129].

The lack of confidence and suspicious attitude towards science, its inaccessibility, and unfamiliarity, could further intensify food neophobia [136]. In this context, suitable application of behavioural science and labelling of this novel product with non-technical terms (such as using term clean meat rather than lab grown meat) could increase its acceptance [135,137]. Thus proper marketing strategies, education and awareness along with effective communication while introducing novel products in market are crucial. Mohorcich and Reese [138] observed the need for proper considerations about unintended intentions of new terminology in intensifying distrust and suspicion amongst consumers. The importance of perception and habits of consumers, production cost and sensory attributes of launched products plays important role in acceptance by consumers and success [24]. The author further observed that lab grown cultured meat having higher acceptance than genetically modified foods and other novel protein sources such as insects. However, that might not be same for regular meat eaters having reservations towards any other meat alternatives, and in-vitro meat has different acceptance in different population groups [137].

The consumer acceptance of new product depends upon both implicit attitudes (may be positive or negative, comprising evaluations without reasoning, better prediction of spontaneous behaviour) and explicit attitudes (reflection of both cognitive elaborations of available knowledge and implicit attitude, assessed by self-report scale) $[139,140]$. It was advocated to avoid depicting cultured meat as alternative to conventional meat rather than emphasizing its inherent benefits / merits associated with its production and consumption to increase its success on commercial scale. [128] surveyed the consumer willingness to purchase cultured meat burger and conventional beef burger with both having equal price and sensory attributes and noted that very small segments (11\%) of respondent of hypothetical survey were ready to purchase it as compared to $65 \%$ ready to buy conventional beef burger. The author also noted the acceptance of in-vitro meat was price sensitive and even a 1 USD increased price of lab meat resulted in 6\% higher acceptance of conventional beef burger. Similar observations had also been reported by other researchers [135,141].

The changing dynamics of meat eating in developed countries owing to ethical, environmental, and safety concerns increase the chances of in-vitro meat success on an industrial scale. Cost of 
cultured meat should be comparable to conventional meat. Slade [128] conducted a survey and concluded that even at the same price, respondents preferred conventional meat (65\%) followed by plant based meat analogs (21\%) and placed in-vitro meat as third place (11\%). Alternatively, thin cultured meat produced in bioreactors could be utilized for preparation of processed meat products such as sausages or burgers, and for complete replica of conventional meat, thicker 3D structure with optimal nutrient and oxygen supply and waste removals from the inner core of cells are required. Additionally cell sheet protocols should be established, as well as a technique for forming a 3D structure for multiple cell types.

\section{SUSTAINABILITY OF IN-VITRO MEAT}

The production of in-vitro meat is considered more extensive and sustainable. The production of cultured meat is still under the developing phase, and at this juncture, it is difficult to prove its sustainability based on available literature. To cater the demand of meat for burgeoning population, there is a need to follow the efficient, innovations, and proper management practices in agriculture and animal rearing and in-vitro meat. We still have limited knowledge of various issues related to the production of in-vitro meat on an industrial scale such as production of growth factors, growth inhibitors and antibiotics used for media preparation on a large scale, efficiency of the whole process, level of energy requirement, amount of waste produced during the process and their proper disposal cost, the volume of GHG emission, etc.

Some countries produce meat more than their requirement and export the surplus to get funds for importing necessary goods. In such a scenario, the adoption of in-vitro meat production at an industrial scale will lead to self-sufficiency in the developed world. This will impact countries relying heavily on the export of meat or live animals.

The in-vitro meat production will be set up near cities or urban centers to reduce transport costs and easier availability of raw materials, and better infrastructure. This production system requires differently trained / skilled manpower, robotic operations, complex equipment and may risk lack of employment of less skilled manpower employed in conventional meat production. Further, animals are not solely reared for meat but used for other purposes such as wool, leather, natural casings, hormones, etc. In several developing countries, animals are still sent to slaughter (spent animals) after completing their productive lives.

There should be a holistic approach and diversification of our food resources for ensuring food security rather than completely relying on a single food resource. Fairlie [142] proposed use of traditional farming, reduction in total meat consumption, in-vitro meat, innovative technologies such nanotechnology, stem cell engineering, synthetic biology for ensure sustainability and better bindings between human and nature.

At present, in-vitro meat is produced commonly in T-flask having $20-22.5 \mathrm{~cm}^{2}$ surface area. For cultured meat production at a large scale by a single unit, multiple $\mathrm{T}$-flasks providing a larger surface area could be utilized. However, this system provides multiple surfaces for cell anchorage but labor intensive as each T-flask to be managed individually [143]. For growing large cells economically by using less culture media with better attachment, properly sealed roller bottles rotating slowly are developed [144]. The automation was introduced to facilitate easier real-time quality control monitoring and process of roller bottles system [145]. Various dextran, cellulose, gelatin or plasticbased micro-sized beads with positively charged outer surfaces were developed for culturing cells on a large scale. These micro-carriers (solid or porous depending upon cell type and preference) attract the negatively charged animal cells [145]. However, micro-carriers suitable for growth, proliferation and differentiation of human stem cells, myoblast expansion, and cultured meat are 
still in developmental phase [146].

Recently certain research findings have raised questions on environmental sustainability merits of in-vitro meat production. Smetana et al. [147] raised concerns over the sustainability of in-vitro meat production and attributed higher environmental impact (in term of ozone layer depletion, ecotoxicity, climate change, human toxicity, land occupation, etc.) of in-vitro meat as compared to plant and dairy based meat alternatives and lower environmental impact than beef and pork owing to its higher energy requirements. Lynch et al. [148] compared the potential increase in temperature in cultured meat vs beef cattle production for 1,000 years in the future on the basis of most prevailing three beef production systems and four in-vitro meat production systems. The authors concluded that actual assessment could be possible by understanding specific environmental input requirements and clean energy production. The authors emphasized the need for detailed analysis of real production systems and life cycle assessment of in-vitro meat. They predicted that lab-grown meat might have certain limitations in the future. McGrath [149] observed the slow but long term adverse effect on the environment during the production of in-vitro meat due to the production of carbon dioxide in place of methane production in beef production. However, as the technology is in the developmental stage, the situation will most likely be changed with the adoption of advanced innovative energy-efficient technologies.

\section{FOOD SAFETY REGULATIONS}

At present, in-vitro meat is not produced on a commercial scale; hence there is no definite regulatory framework in place. The prevailing food safety regulations of a country will be applied to this novel product as such. As the whole process of cell culturing is performed at strict hygienic and sterile conditions, and whenever, incidences of any contaminations are come across at any stage of production, the whole process is immediately aborted and corrected. Specht et al [150] found that all ingredients required for production should be sourced as food ingredients. In USA, joint regulatory framework for cultured meat was proposed by Food and Drug Administration (FDA) and Food Safety and Inspection Service (FSIS) in 2018, with FDA overlooking cell collection, cell banks, cells proliferation and differentiation stages whereas FSIS regulating cell harvesting and labelling of end product originated from cell cultures obtained from livestock and poultry [44]. In EU the regulations as applied for Novel Foods will be applicable to cultured meat.

Although cell culturing is completed under strict hygienic conditions and quality control in bioreactors and thus posing fewer microbiological and chemical hazards as compared to conventional slaughtering and dressing operations. Once outside the bioreactors, these cells have an equal risk of contamination and health hazards similar to conventional meat. Besides this, the genetic instability of cell divisions also requires due attention [35]. However, consumption of properly cooked in-vitro meat would not pose any health problems. The preparation of various processed meat products from in-vitro meat will need proper identifications of various hazards and implementation of Hazard Analysis Critical Control Points (HACCP)-based system [26]. Under prevailing regulations in EU and US, in-vitro meat does not fall in the ambit of meat category, and meat industry is not ready to accept it as meat. However, allergy and health concerns associated with cultured meat may improve the prevailing norms [142]. In the future, a regulatory framework would be in place for new challenges such as fraud cases as selling cultured meat as conventional meat and vice versa and mislabeling of cultured meat as conventional meat and vice versa. 


\section{FUTURE PERSPECTIVE}

The success and acceptability of any new technology such as in-vitro meat is mostly determined by its acceptance among end-users, awareness about its beneficial effects, constraints, and its sustainability at a reasonable price. As in-vitro meat production is a new and developing technology, there are several challenges in the beginning with respect to its adaptation on an industrial scale, similar to the adoption of any new technology. Theoretically, it is possible to produce 1 billion beef burgers, each weighing $113 \mathrm{~g}$ within 45 days from a single biopsy from a single cow provided with Hayflick limit of mesenchymal cell division 50, [151] whereas equal number of burger production would require slaughter of 0.5 billion cows over 1.5 years age [4].

The potential production at commercial scale and market share of in-vitro meat remain debatable. Scientists have different opinions such as Bekker et al. [126] and Verbeke et al. [152] predicted good market share and consumer acceptance of in-vitro meat, whereas, other researchers have noted the lower acceptance of in-vitro meat $[21,132,141,152]$. In the future mainly due to unnaturalness and not believing in its potential to solve all issues associated with meat production.

Food played an important role in shaping the socio-cultural and economic conditions of humans. It is tendency of human being to always search food with better sensory attributes and nutrient quality. It increased our efforts to search for meat alternatives leading to popularity for alternative eating for alternative protein sources $[153,154]$. The consumer confidence towards accepting novel food products could be improved by applying advanced processing tools, cooling technologies, better implementation of sanitary and phytosanitary measure [155-158].

There are several incidences of zoonotic diseases and meat borne illness and toxicity outbreaks recorded in every year in the world. The increasing non-judicious use of antibiotics, hormones, growth factors, etc. in animal production and meat processing and preservation increased the risk of toxic or drug residue in meat and posing serious health issue in near future [130]. Thus in such a scenario, in-vitro meat will provide a far better and safe alternative to conventional meat to a great extent.

Of-course, in-vitro meat will improve animal protein supply and food security along with environmental and ethical benefits. However, these benefits are not certain as there is still great degree of uncertainty and unintended consequences in future [25]. The scientific community has not reached a unanimous viewpoint about the advantages and risks of in-vitro meat production and its popularization on a commercial scale. It is very important to identify and rectify the unfavorable aspects that may hinder the commercialization of in-vitro meat. Bruce Friedrich, Director of the Global Food Initiative (GFI), in his keynote address on Alternative Protein Show in Jan 2019 noted that in the future, the consumer acceptance of in-vitro meat would depend upon its competition with animal agriculture whole not just based on ethical considerations [159]. Alternatively, it can be concluded that environmental, ethical and socio economic benefits of in-vitro meat could be perceived only when it would be accepted by consumers and produced at commercial scale.

\section{CONCLUSION}

The production of meat by cell culture is having several advantages over conventional meat production such as production of various kinds of meat without performing actual slaughter, less resource intensive and huge potential to cater the rising demand of meat in future. However, the technology should be cost effective and the product retrieved should have similar organoleptic and functional attributes as that of conventional meat. Scientific community is continuously searching for better sustainable inputs of production especially animal-free media, pluripotent 
cells with higher Hayflick limit, nutrient supply, improved scaffold material and designs and developing products similar to conventional meat by using 3D and 3D bioprinting, coculturing, tissue engineering, etc. There is a need for product oriented publicity, proper nomenclature and information about product development to increase consumer's acceptance and awareness to tackle food neophobia, disgust and unnatural feelings.

\section{REFERENCES}

1. Pereira PMCC, Vicente AFRB. Meat nutritional composition and nutritive role in the human diet. Meat Sci. 2013;93:586-92. https://doi.org/10.1016/j.meatsci.2012.09.018

2. Kumar P, Kumar S, Tripathi MK, Mehta N, Ranjan R, Bhat ZF, et al. Flavonoids in the development of functional meat products: a review. Vet World. 2013;6:573-8. https://doi. org/10.5455/vetworld.2013.573-578

3. Schmidhuber J, Pound J, Qiao B. COVID-19: channels of transmission to food and agriculture. Rome, Italy: Food and Agriculture Organization of the United Nations; 2020.

4. Sans P, Combris P. World meat consumption patterns: an overview of the last fifty years (1961-2011). Meat Sci. 2015;109:106-11. https://doi.org/10.1016/j.meatsci.2015.05.012

5. Tonsor GT, Schulz LL. Will an incentive-compatible indemnity policy please stand up? Livestock producer willingness to self-protect. Transbound Emerg Dis. 2020;67:2713-30. https:// doi.org/10.1111/tbed.13626

6. Steinfeld H, Gerber P, Wassenaar TD, Castel V, Rosales M, Rosales M, et al. Livestock's long shadow: environmental issues and options. Rome, Italy: Food and Agriculture Organization of the United Nations; 2006.

7. Bruinsma J. Resource outlook to 2050: by how much do land, water and crop yields need to increase by 2050? Paper presented at the FAO expert meeting on how to feed the world in 2050; 2009 June 24-26; Rome, Italy.

8. Kumar P, Mehta N, Malav OP, Verma AK, Umraw P, Kanth MK. The structure of meat analogs. In: Melton L, Shahidi F, Varelis P, editors. Encyclopedia of food chemistry. vol. 3. Cambridge, MA: Elsevier; 2019.

9. Pimentel D, Pimentel M. Sustainability of meat-based and plant-based diets and the environment. Am J Clin Nutr. 2003;78:660S-3S. https://doi.org/10.1093/ajcn/78.3.660S

10. Aiking H. Future protein supply. Trends Food Sci Technol. 2011;22:112-20. https://doi. org/10.1016/j.tifs.2010.04.005

11. Kumar P, Chatli MK, Verma AK, Mehta N, Malav OP, Kumar D, et al. Quality, functionality, and shelf life of fermented meat and meat products: a review. Crit Rev Food Sci Nutr. 2017;57:2844-56. https://doi.org/10.1080/10408398.2015.1074533

12. Mayfield LE, Bennett R, Tranter R, Wooldridge MJ. Consumption of welfare-friendly food products in Great Britain, Italy and Sweden, and how it may be influenced by consumer attitudes to, and behaviour towards, animal welfare attributes. Int J Sociol. 2007;15:59-70.

13. Raney T, Skoet J, Steinfeld H. The state of food and agriculture: livestock in the balance. Rome, Italy: Food and Agriculture Organization of the United Nations; 2009.

14. Mehta N, Kumar P, Verma AK, Umaraw P, Ranjan R. Missing the real culprit? Insight on the water footprint of the meat Industry. Fleishwirtschaft Int. 2021;2:54-8.

15. Falkenmark M, Lundqvist J, Berntell A, Blenckner S, Trouba D, Molden D, et al. Water: more nutrition per drop: towards sustainable food production and consumption patterns in a rapidly changing world [Internet]. Stockholm International Water Institute. 2004. [cited 2021 May 7]. https://www.swedishwaterhouse.se/wp-content/uploads/CSD_More_nutri- 
tion_per_drop_2004.pdf

16. Ye L, Van Ranst E. Production scenarios and the effect of soil degradation on long-term food security in China. Glob Environ Change. 2009;19:464-81. https://doi.org/10.1016/j.gloenvcha.2009.06.002

17. Salter AM. The effects of meat consumption on global health. Rev Sci Technol. 2018;37:4755. https://doi.org/10.20506/rst.37.1.2739

18. Nutrition Today. Dietary guidelines advisory committee reports. Nutr Today. 1985;20:8-15. https://doi.org/10.1097/00017285-198505000-00002

19. CDC [Centers for Disease Control and Prevention.]. Antibiotic resistance threats in the United States, 2013. Atlanta, GA: U.S. Department of Health and Human Services; 2013.

20. Springmann M, Clark M, Mason-D'Croz D, Wiebe K, Bodirsky BL, Lassaletta L, et al. Options for keeping the food system within environmental limits. Nature. 2018;562:519-25. https://doi.org/10.1038/s41586-018-0594-0

21. Verbeke W, Marcu A, Rutsaert P, Gaspar R, Seibt B, Fletcher D, et al. 'Would you eat cultured meat?': consumers' reactions and attitude formation in Belgium, Portugal and the United Kingdom. Meat Sci. 2015;102:49-58. https://doi.org/10.1016/j.meatsci.2014.11.013

22. Peters A. Lab-grown meat is getting cheap enough for anyone to buy [Internet]. Fast Company. 2018 [cited 2021 May 7]. https://www.fastcompany.com/40565582/lab-grown-meatis-getting-cheap-enough-for-anyone-to-buy

23. Bhat ZF, Kumar S, Bhat HF. In vitro meat: a future animal-free harvest. Crit Rev Food Sci Nutr. 2017;57:782-9. https://doi.org/10.1080/10408398.2014.924899

24. Bryant C, Szejda K, Parekh N, Deshpande V, Tse B. A survey of consumer perceptions of plant-based and clean meat in the USA, India, and China. Front Sustain Food Syst. 2019;3:11. https://doi.org/10.3389/fsufs.2019.00011

25. Mattick CS, Landis AE, Allenby BR. A case for systemic environmental analysis of cultured meat.J Integr Agric. 2015;14:249-54. https://doi.org/10.1016/S2095-3119(14)60885-6

26. Stephens N, Di Silvio L, Dunsford I, Ellis M, Glencross A, Sexton A. Bringing cultured meat to market: technical, socio-political, and regulatory challenges in cellular agriculture. Trends Food Sci Technol. 2018;78:155-66. https://doi.org/10.1016/j.tifs.2018.04.010

27. Bhat ZF, Kumar S, Fayaz H. In vitro meat production: challenges and benefits over conventional meat production. J Integr Agric. 2015;14:241-8. https://doi.org/10.1016/S20953119(14)60887-X

28. Post MJ, Levenberg S, Kaplan DL, Genovese N, Fu J, Bryant CJ, et al. Scientific, sustainability and regulatory challenges of cultured meat. Nat Food. 2020;1:403-15. https://doi. org/10.1038/s43016-020-0112-z

29. Hong TK, Shin DM, Choi J, Do JT, Han SG. Current issues and technical advances in cultured meat production: a review. Food Sci Anim Resour. 2021;41:355-72. https://doi. org/10.5851/kosfa.2021.e14

30. Sharma S, Thind SS, Kaur A. In vitro meat production system: why and how? J Food Sci Technol. 2015;52:7599-607. https://doi.org/10.1007/s13197-015-1972-3

31. Carrington D. No-kill, lab-grown meat to go on sale for first time [Internet]. Guardian News \& Media. 2020 [cited 2021 May 7]. https://www.theguardian.com/environment/2020/ dec/02/no-kill-lab-grown-meat-to-go-on-sale-for-first-time

32. Bhat ZF, Morton JD, Mason SL, Bekhit AEDA, Bhat HF. Technological, regulatory, and ethical aspects of in vitro meat: a future slaughter-free harvest. Compr Rev Food Sci Food Saf. 2019;18:1192-208. https://doi.org/10.1111/1541-4337.12473

33. Kramer C. In vitro meat is... a name. Food Phreaking. 2016;2:30-6. 
34. Friedrich B. Clean meat: the "clean energy" of food [Internet]. Huffpost. 2016 [cited 2021 May 7]. https://www.huffpost.com/entry/clean-meat-the-clean-energy-of-food_b_ 57cee00ee4b0f831f705a879

35. Hocquette JF. Is in vitro meat the solution for the future? Meat Sci. 2016;120:167-76. https:// doi.org/10.1016/j.meatsci.2016.04.036

36. Eschner K. Winston Churchill imagined the lab-grown hamburger [Internet]. Smithsonian Magazine. 2017 [cited 2021 May 7]. https://www.smithsonianmag.com/smart-news/winston-churchill-imagined-lab-grown-hamburger-180967349/

37. Jiang L. Alexis Carrel's immortal chick heart tissue cultures (1912-1946) [Internet]. The Embryo Project Encyclopedia. The Embryo Project at Arizona State University. 2012 [cited 2021 May 7]. https://embryo.asu.edu/pages/alexis-carrels-immortal-chick-heart-tissue-cultures-1912-1946

38. Van Eelen WF, van Kooten WJ, Westerhof W. Industrial production of meat from in vitro cell cultures. World Intellectual Property Organization Patent WO/99/31222. 1999 June 24.

39. Benjaminson MA, Gilchriest JA, Lorenz M. In vitro edible muscle protein production system (MPPS): stage 1, fish. Acta Astronaut. 2002;51:879-89.https://doi.org/10.1016/S00945765(02)00033-4

40. Tuomisto HL, de Mattos MJT. Environmental impacts of cultured meat production. Environ Sci Technol. 2011;45:6117-23. https://doi.org/10.1021/es200130u

41. Timilsena YP, Wang B, Adhikari R, Adhikari B. Advances in microencapsulation of polyunsaturated fatty acids (PUFAs)-rich plant oils using complex coacervation: a review. Food Hydrocoll. 2017;69:369-81. https://doi.org/10.1016/j.foodhyd.2017.03.007

42. Langelaan MLP, Boonen KJM, Polak RB, Baaijens FPT, Post MJ, van der Schaft DWJ. Meet the new meat: tissue engineered skeletal muscle. Trends Food Sci Technol. 2010;21:59-66. https://doi.org/10.1016/j.tifs.2009.11.001

43. Post MJ. Cultured beef: medical technology to produce food.J Sci Food Agric. 2014;94:103941. https://doi.org/10.1002/jsfa.6474

44. Choudhury D, Tseng TW, Swartz E. The business of cultured meat. Trends Biotechnol. 2020;38:573-7. https://doi.org/10.1016/j.tibtech.2020.02.012

45. Scipioni J. Lab-grown meat makes world debut at Singapore restaurant [Internet]. 2020 [cited 2021 May 7]. https:/www.cnbc.com/2020/12/18/singapore-restaurant-first-ever-to-serveeat-just-lab-grown-chicken.html

46. Mridul A. Cultured meat to hit UK menus by 2023, says cell-based startup Ivy Farm [Internet]. The Vegan Review. 2021 [cited 2021 May 7]. https://theveganreview.com/cultured-meat-ukmenus-2023-cell-based-startup-ivy-farm/

47. Bartholet J. Inside the meat lab. Sci Am. 2011;304:64-9. https://doi.org/10.1038/scientificamerican0611-64

48. Tuomisto HL, Roy AG. Could cultured meat reduce environmental impact of agriculture in Europe. In: Proceedings of the 8th International Conference on Life Cycle Assessment in the Agri-Food Sector; 2012; Saint-Malo, France.

49. Suresh S. "Friend" or "Fiend": in vitro lab meat and how Canada might regulate its production and sale. Ottawa, ON: The Canadian Agri-Food Policy Institute; 2018.

50. Dennis RG, Kosnik PE 2nd. Excitability and isometric contractile properties of mammalian skeletal muscle constructs engineered in vitro. In Vitro Cell Dev Biol Anim. 2000;36:327-35. https://doi.org/10.1290/1071-2690(2000)036\%3C0327:EAICPO\%3E2.0.CO;2

51. Post MJ, Hocquette JF. Chapter 16 - New sources of animal proteins: cultured meat. In: Purslow PP, editor. New aspects of meat quality: from genes to ethics. Sawston: Woodhead; 2017.p. 
425-41.

52. Arshad MS, Javed M, Sohaib M, Saeed F, Imran A, Amjad Z. Tissue engineering approaches to develop cultured meat from cells: a mini review. Cogent Food Agric. 2017;3:1320814. https://doi.org/10.1080/23311932.2017.1320814

53. Mann A, Yadav RP, Singh J, Kumar D, Singh B, Yadav PS. Culture, characterization and differentiation of cells from buffalo (Bubalus bubalis) amnion. Cytotechnology. 2013;65:23-30. https://doi.org/10.1007/s10616-012-9464-z

54. Sharma N, Kim JH, Sodhi SS, Luong DH, Kim SW, Oh SJ, et al. Differentiation dynamics of mammary epithelial stem cells from Korean holstein dairy cattle under ECM-free conditions. J Biomol Struct Dyn. 2015;33:2633-54. https://doi.org/10.1080/07391102.2014.10031 97

55. Edelman PD, McFarland DC, Mironov VA, Matheny JG. Commentary: in vitro-cultured meat production. Tissue Eng. 2005;11:659-62. https://doi.org/10.1089/ten.2005.11.659

56. Ezashi T, Telugu BPVL, Alexenko AP, Sachdev S, Sinha S, Roberts RM. Derivation of induced pluripotent stem cells from pig somatic cells. Proc Natl Acad Sci USA. 2009;106:10993-8. https://doi.org/10.1073/pnas.0905284106

57. Mizuno Y, Chang H, Umeda K, Niwa A, Iwasa T, Awaya T, et al. Generation of skeletal muscle stem/progenitor cells from murine induced pluripotent stem cells. FASEB J. 2010;24:2245-53. https://doi.org/10.1096/fj.09-137174

58. Hopkins PD, Dacey A. Vegetarian meat: could technology save animals and satisfy meat eaters? J Agric Environ Ethics. 2008;21:579-96. https://doi.org/10.1007/s10806-008-9110-0

59. Shi X, Garry DJ. Muscle stem cells in development, regeneration, and disease. Genes Dev. 2006;20:1692-708. https://doi.org/10.1101/gad.1419406

60. Dumont NA, Wang YX, Rudnicki MA. Intrinsic and extrinsic mechanisms regulating satellite cell function. Development. 2015;142:1572-81. https://doi.org/10.1242/dev.114223

61. Sodhi SS, Sharma N, Ghosh M, Sethi RS, Jeong DK, Lee SJ. Differential expression patterns of myogenic regulatory factors in the postnatal longissimus dorsi muscle of Jeju Native Pig and Berkshire breeds along with their co-expression with Pax7. Electron J Biotechnol. 2021;51:8-16. https://doi.org/10.1016/j.ejbt.2021.03.001

62. Carrier RL, Papadaki M, Rupnick M, Schoen FJ, Bursac N, Langer R, et al. Cardiac tissue engineering: cell seeding, cultivation parameters, and tissue construct characterization. Biotechnol Bioeng. 1999;64:580-9. https://doi.org/10.1002/(SICI)10970290(19990905)64:5\%3C580::AID-BIT8\%3E3.0.CO;2-X

63. Singh A, Verma V, Kumar M, Kumar A, Sarma DK, Singh B, et al. Stem cells-derived in vitro meat: from petri dish to dinner plate. Crit Rev Food Sci Nutr. 2020. https://doi.org/10.10 80/10408398.2020.1856036

64. Zandonella C. Tissue engineering: the beat goes on. Nature. 2003;421:884-6. https://doi. org/10.1038/421884a

65. Datar I, Betti M. Possibilities for an in vitro meat production system. Innov Food Sci Emerg Technol.2010;11:13-22. https://doi.org/10.1016/j.ifset.2009.10.007

66. Dennis RG, Kosnik PE 2nd, Gilbert ME, Faulkner JA. Excitability and contractility of skeletal muscle engineered from primary cultures and cell lines. Am J Physiol Cell Physiol. 2001;280:C288-95. https://doi.org/10.1152/ajpcell.2001.280.2.C288

67. Wolfson W. Raising the steaks. New Sci. 2002;176:60-3.

68. Gillispie GJ, Park J, Copus JS, Asari AKPR, Yoo JJ, Atala A, et al. Three-dimensional tissue and organ printing in regenerative medicine. In: Atala A, Lanza R, Nerem R, editors. Principles of regenerative medicine. 3rd ed. London: Academic Press; 2019. p. 831-52. 
69. Jandyal M, Malav OP, Chatli MK. 3D printing of meat : a new frontier of food from download to delicious : a review. Int J Curr Microbiol Appl Sci. 2021;10:2095-111.

70. Javaid M, Haleem A. 4D printing applications in medical field: a brief review. Clin Epidemiol Glob Health. 2019;7:317-21. https://doi.org/10.1016/j.cegh.2018.09.007

71. Murphy SV, Atala A. 3D bioprinting of tissues and organs. Nat Biotechnol. 2014;32:773-85. https://doi.org/10.1038/nbt.2958

72. Mandrycky C, Wang Z, Kim K, Kim DH. 3D bioprinting for engineering complex tissues. Biotechnol Adv. 2016;34:422-34. https://doi.org/10.1016/j.biotechadv.2015.12.011

73. Kingsley DJ, Ranjan S, Dasgupta N, Saha P. Nanotechnology for tissue engineering: need, techniques and applications. J Pharm Res. 2013;7:200-4. https://doi.org/10.1016/j.jopr.2013.02.021

74. Jiao A, Trosper NE, Yang HS, Kim J, Tsui JH, Frankel SD, et al. Thermoresponsive nanofabricated substratum for the engineering of three-dimensional tissues with layer-by-layer architectural control. ACS Nano. 2014;8:4430-9. https://doi.org/10.1021/nn4063962

75. Kim ES, Ahn EH, Dvir T, Kim DH. Emerging nanotechnology approaches in tissue engineering and regenerative medicine. Int J Nanomedicine. 2014;9 Suppl 1:1-5. https://doi. org/10.2147/IJN.S61212

76. Shapira A, Kim DH, Dvir T. Advanced micro- and nanofabrication technologies for tissue engineering. Biofabrication. 2014;6:020301. https://doi.org/10.1088/1758-5082/6/2/020301

77. Coecke S, Balls M, Bowe G, Davis J, Gstraunthaler G, Hartung T, et al. Guidance on good cell culture practice: a report of the second ECVAM task force on good cell culture practice. Altern Lab Anim. 2005;33:261-87. https://doi.org/10.1177/026119290503300313

78. Ford BJ. Critical focus: cultured meat: food for the future. Microsc Chic. 2011;59:73-81.

79. Smith AST, Passey S, Greensmith L, Mudera V, Lewis MP. Characterization and optimization of a simple, repeatable system for the long term in vitro culture of aligned myotubes in 3D.J Cell Biochem. 2012;113:1044-53. https://doi.org/10.1002/jcb.23437

80. Chiron S, Tomczak C, Duperray A, Lainé J, Bonne G, Eder A, et al. Complex interactions between human myoblasts and the surrounding 3D fibrin-based matrix. PLOS ONE. 2012;7:e36173. https://doi.org/10.1371/journal.pone.0036173

81. Fujita H, Endo A, Shimizu K, Nagamori E. Evaluation of serum-free differentiation conditions for $\mathrm{C} 2 \mathrm{C} 12$ myoblast cells assessed as to active tension generation capability. Biotechnol Bioeng. 2010;107:894-901. https://doi.org/10.1002/bit.22865

82. Aswad H, Jalabert A, Rome S. Depleting extracellular vesicles from fetal bovine serum alters proliferation and differentiation of skeletal muscle cells in vitro. BMC Biotechnol. 2016;16:32. https://doi.org/10.1186/s12896-016-0262-0

83. Choi KH, Yoon JW, Kim M, Lee HJ, Jeong J, Ryu M, et al. Muscle stem cell isolation and in vitro culture for meat production: a methodological review. Compr Rev Food Sci Food Saf. 2021;20:429-57. https://doi.org/10.1111/1541-4337.12661

84. Menkem ZE, Ngangom BL, Tamunjoh SSA, Boyom FF. Antibiotic residues in food animals: public health concern. Acta Ecol Sin. 2019;39:411-5. https://doi.org/10.1016/j.chnaes.2018.10.004

85. Ben-Arye T, Shandalov Y, Ben-Shaul S, Landau S, Zagury Y, Ianovici I, et al. Textured soy protein scaffolds enable the generation of three-dimensional bovine skeletal muscle tissue for cell-based meat. Nat Food. 2020;1:210-20. https://doi.org/10.1038/s43016-020-0046-5

86. Zeltinger J, Sherwood JK, Graham DA, Müeller R, Griffith LG. Effect of pore size and void fraction on cellular adhesion, proliferation, and matrix deposition. Tissue Eng. 2001;7:557-72. https://doi.org/10.1089/107632701753213183 
87. Hwang CM, Sant S, Masaeli M, Kachouie NN, Zamanian B, Lee SH, et al. Fabrication of three-dimensional porous cell-laden hydrogel for tissue engineering. Biofabrication. 2010;2:035003. https://doi.org/10.1088/1758-5082/2/3/035003

88. Haagsman HP, Hellingwerf KJ, Roelen BAJ. Production of animal proteins by cell systems: desk study on cultured meat ("kweekvlees") [Internet].2009 [cited 2021 May 7]. http://citeseerx.ist.psu.edu/viewdoc/download?doi=10.1.1.732.9877\&rep=rep1\&type=pdf

89. Engler AJ, Griffin MA, Sen S, Bönnemann CG, Sweeney HL, Discher DE. Myotubes differentiate optimally on substrates with tissue-like stiffness: pathological implications for soft or stiff microenvironments. J Cell Biol. 2004;166:877-87. https://doi.org/10.1083/ jcb.200405004

90. Choi YJ, Kim TG, Jeong J, Yi HG, Park JW, Hwang W, et al. 3D cell printing of functional skeletal muscle constructs using skeletal muscle-derived bioink. Adv Healthc Mater. 2016;5:2636-45. https://doi.org/10.1002/adhm.201600483

91. Kim W, Lee H, Lee J, Atala A, Yoo JJ, Lee SJ, et al. Efficient myotube formation in 3D bioprinted tissue construct by biochemical and topographical cues. Biomaterials. 2020;230:119632. https://doi.org/10.1016/j.biomaterials.2019.119632

92. Ostrovidov S, Shi X, Zhang L, Liang X, Kim SB, Fujie T, et al. Myotube formation on gelatin nanofibers - multi-walled carbon nanotubes hybrid scaffolds. Biomaterials. 2014;35:6268-77. https://doi.org/10.1016/j.biomaterials.2014.04.021

93. MacQueen LA, Alver CG, Chantre CO, Ahn S, Cera L, Gonzalez GM, et al. Muscle tissue engineering in fibrous gelatin: implications for meat analogs. npj Sci Food. 2019;3:20. https:// doi.org/10.1038/s41538-019-0054-8

94. Orellana N, Sánchez E, Benavente D, Prieto P, Enrione J, Acevedo CA. A new edible film to produce in vitro meat. Foods. 2020;9:185. https://doi.org/10.3390/foods9020185

95. Tomiyama AJ, Kawecki NS, Rosenfeld DL, Jay JA, Rajagopal D, Rowat AC. Bridging the gap between the science of cultured meat and public perceptions. Trends Food Sci Technol. 2020;104:144-52. https://doi.org/10.1016/j.tifs.2020.07.019

96. Allan SJ, De Bank PA, Ellis MJ. Bioprocess design considerations for cultured meat production with a focus on the expansion bioreactor. Front Sustain Food Syst. 2019;3:44. https://doi. org/10.3389/fsufs.2019.00044

97. Canavan HE, Cheng X, Graham DJ, Ratner BD, Castner DG. Cell sheet detachment affects the extracellular matrix: a surface science study comparing thermal liftoff, enzymatic, and mechanical methods. J Biomed Mater Res A. 2005;75A:1-13. https://doi.org/10.1002/jbm. a.30297

98. da Silva RMP, Mano JF, Reis RL. Smart thermoresponsive coatings and surfaces for tissue engineering: switching cell-material boundaries. Trends Biotechnol. 2007;25:577-83. https:// doi.org/10.1016/j.tibtech.2007.08.014

99. Lam MT, Huang YC, Birla RK, Takayama S. Microfeature guided skeletal muscle tissue engineering for highly organized 3-dimensional free-standing constructs. Biomaterials. 2009;30:1150-5. https://doi.org/10.1016/j.biomaterials.2008.11.014

100. Cheng YW, Shiwarski DJ, Ball RL, Whitehead KA, Feinberg AW. Engineering aligned skeletal muscle tissue using decellularized plant-derived scaffolds. ACS Biomater Sci Eng. 2020;6:3046-54. https://doi.org/10.1021/acsbiomaterials.0c00058

101. Pandurangan M, Kim DH. A novel approach for in vitro meat production. Appl Microbiol Biotechnol. 2015;99:5391-5. https://doi.org/10.1007/s00253-015-6671-5

102. Boney CM, Moats-Staats BM, Stiles AD, D'Ercole AJ. Expression of insulin-like growth factor-I (IGF-I) and IGF-binding proteins during adipogenesis. Endocrinology. 
1994;135:1863-8. https://doi.org/10.1210/endo.135.5.7525256

103. Pandurangan M, Jeong D, Amna T, Van Ba H, Hwang I. Co-culture of C2C12 and 3T3-L1 preadipocyte cells alters the gene expression of calpains, caspases and heat shock proteins. In Vitro Cell Dev Biol Anim. 2012;48:577-82. https://doi.org/10.1007/s11626-012-9550-8

104. Kino-oka M, Kim J, Kurisaka K, Kim MH. Preferential growth of skeletal myoblasts and fibroblasts in co-culture on a dendrimer-immobilized surface. J Biosci Bioeng. 2013;115:96-9. https://doi.org/10.1016/j.jbiosc.2012.08.012

105. Lowe KC. Blood substitutes: from chemistry to clinic. J Mater Chem. 2006;16:4189-96. https://doi.org/10.1039/B604923K

106. Martin I, Wendt D, Heberer M. The role of bioreactors in tissue engineering. Trends Biotechnol. 2004;22:80-6. https://doi.org/10.1016/j.tibtech.2003.12.001

107. Schnitzler AC, Verma A, Kehoe DE, Jing D, Murrell JR, Der KA, et al. Bioprocessing of human mesenchymal stem/stromal cells for therapeutic use: current technologies and challenges. Biochem Eng J. 2016;108:3-13. https://doi.org/10.1016/j.bej.2015.08.014

108. Bhat ZF, Fayaz H. Prospectus of cultured meat—advancing meat alternatives. J Food Sci Technol. 2011;48:125-40. https://doi.org/10.1007/s13197-010-0198-7

109. Carrier RL, Rupnick M, Langer R, Schoen FJ, Freed LE, Vunjak-Novakovic G. Perfusion improves tissue architecture of engineered cardiac muscle. Tissue Eng. 2002;8:175-88. https:// doi.org/10.1089/107632702753724950

110. Levenberg S, Rouwkema J, Macdonald M, Garfein ES, Kohane DS, Darland DC, et al. Engineering vascularized skeletal muscle tissue. Nat Biotechnol. 2005;23:879-84. https://doi. org/10.1038/nbt1109

111. Radisic M, Marsano A, Maidhof R, Wang Y, Vunjak-Novakovic G. Cardiac tissue engineering using perfusion bioreactor systems. Nat Protoc. 2008;3:719-38. https://doi.org/10.1038/ nprot.2008.40

112. Moritz MSM, Verbruggen SEL, Post MJ. Alternatives for large-scale production of cultured beef: a review. J Integr Agric. 2015;14:208-16. https://doi.org/10.1016/S20953119(14)60889-3

113. Ramboer E, De Craene B, De Kock J, Vanhaecke T, Berx G, Rogiers V, et al. Strategies for immortalization of primary hepatocytes. J Hepatol. 2014;61:925-43. https://doi.org/10.1016/ j.jhep.2014.05.046

114. Genovese NJ, Domeier TL, Telugu BPVL, Roberts RM. Enhanced development of skeletal myotubes from porcine induced pluripotent stem cells. Sci Rep. 2017;7:41833. https://doi. org $/ 10.1038 /$ srep41833

115. Oikonomopoulos A, van Deen WK, Manansala AR, Lacey PN, Tomakili TA, Ziman A, et al. Optimization of human mesenchymal stem cell manufacturing: the effects of animal/xeno-free media. Sci Rep. 2015;5:16570. https://doi.org/10.1038/srep16570

116. Jairath G, Mal G, Gopinath D, Singh B. An holistic approach to access the viability of cultured meat: a review. Trends Food Sci Technol. 2021;110:700-10. https://doi.org/10.1016/ j.tifs.2021.02.024

117. Kanatous SB, Mammen PPA. Regulation of myoglobin expression. J Exp Biol. 2010;213:2741-7. https://doi.org/10.1242/jeb.041442

118. Fraeye I, Kratka M, Vandenburgh H, Thorrez L. Sensorial and nutritional aspects of cultured meat in comparison to traditional meat: much to be inferred. Front Nutr. 2020;7:35. https:// doi.org/10.3389/fnut.2020.00035

119. Simsa R, Yuen J, Stout A, Rubio N, Fogelstrand P, Kaplan DL. Extracellular heme proteins influence bovine myosatellite cell proliferation and the color of cell-based meat. Foods (Basel, 
Switzerland). 2019;8:521. https://doi.org/10.3390/foods8100521

120. Fish KD, Rubio NR, Stout AJ, Yuen JSK, Kaplan DL. Prospects and challenges for cell-cultured fat as a novel food ingredient. Trends Food Sci Technol. 2020;98:53-67. https://doi. org/10.1016/j.tifs.2020.02.005

121. Frank D, Ball A, Hughes J, Krishnamurthy R, Piyasiri U, Stark J, et al. Sensory and flavor chemistry characteristics of Australian beef: influence of intramuscular fat, feed, and breed. J Agric Food Chem. 2016;64:4299-311. https://doi.org/10.1021/acs.jafc.6b00160

122. Mannello F, Tonti GA. Concise review: no breakthroughs for human mesenchymal and embryonic stem cell culture: conditioned medium, feeder layer, or feeder-free; medium with fetal calf serum, human serum, or enriched plasma; serum-free, serum replacement nonconditioned medium, or ad hoc formula? All that glitters is not gold! Stem Cells. 2007;25:1603-9. https:// doi.org/10.1634/stemcells.2007-0127

123. Bian W, Bursac N. Engineered skeletal muscle tissue networks with controllable architecture. Biomaterials. 2009;30:1401-12. https://doi.org/10.1016/j.biomaterials.2008.11.015

124. Snyman C, Goetsch KP, Myburgh KH, Niesler CU. Simple silicone chamber system for in vitro three-dimensional skeletal muscle tissue formation. Front Physiol. 2013;4:349. https:// doi.org/10.3389/fphys.2013.00349

125. Sandvig I, Karstensen K, Rokstad AM, Aachmann FL, Formo K, Sandvig A, et al. RGD-peptide modified alginate by a chemoenzymatic strategy for tissue engineering applications.J Biomed Mater Res A. 2015;103A:896-906. https://doi.org/10.1002/jbm.a.35230

126. Bekker GA, Fischer ARH, Tobi H, van Trijp HCM. Explicit and implicit attitude toward an emerging food technology: the case of cultured meat. Appetite. 2017;108:245-54. https://doi. org/10.1016/j.appet.2016.10.002

127. Schwartz D. NT Cattlemen's Association to hear that 'cultured meat'could end their industry within decades [Internet]. ABC News. 2015 [cited 2021 May 7]. https://www.abc.net.au/ $\mathrm{am} /$ content/2015/s4205857.htm

128. Slade P. If you build it, will they eat it? Consumer preferences for plant-based and cultured meat burgers. Appetite. 2018;125:428-37. https://doi.org/10.1016/j.appet.2018.02.030

129. van der Weele C, Tramper J. Cultured meat: every village its own factory? Trends Biotechnol. 2014;32:294-6. https://doi.org/10.1016/j.tibtech.2014.04.009

130. Umaraw P, Verma AK. Consumer perception changes meat products. Fleischwirtschaft Int J Meat Prod Meat Process. 2016;2016:58-67.

131. Anand SS, Hawkes C, de Souza RJ, Mente A, Dehghan M, Nugent R, et al. Food consumption and its impact on cardiovascular disease: importance of solutions focused on the globalized food system: a report from the workshop convened by the World Heart Federation. J Am Coll Cardiol. 2015;66:1590-614. https://doi.org/10.1016/j.jacc.2015.07.050

132. Hocquette JF, Mainsant P, Daudin JD, Cassar-malek I, Rémond D, Doreau M, et al. Will meat be produced in vitro in the future? Prod Anim. 2013;26:363-74. https://doi. org/10.20870/productions-animales.2013.26.4.3164

133. Goodwin JN, Shoulders CW. The future of meat: a qualitative analysis of cultured meat media coverage. Meat Sci. 2013;95:445-50. https://doi.org/10.1016/j.meatsci.2013.05.027

134. Verbeke W. Consumer attitudes and communication challenges for agro-food technologies. Agro Food Ind Hi-Tech. 2011;22:34-6.

135. Siegrist M, Sütterlin B, Hartmann C. Perceived naturalness and evoked disgust influence acceptance of cultured meat. Meat Sci. 2018;139:213-9. https://doi.org/10.1016/j.meatsci.2018.02.007

136. Sinatra GM, Hofer BK. Public understanding of science: policy and educational implications. 
Policy Insights Behav Brain Sci. 2016;3:245-53. https://doi.org/10.1177/2372732216656870

137. Bryant C, Barnett J. Consumer acceptance of cultured meat: an updated review (2018-2020). Appl Sci. 2020;10:5201. https://doi.org/10.3390/app10155201

138. Mohorčich J, Reese J. Cell-cultured meat: lessons from GMO adoption and resistance. Appetite. 2019;143:104408. https://doi.org/10.1016/j.appet.2019.104408

139. Gawronski B, Bodenhausen GV. Associative and propositional processes in evaluation: an integrative review of implicit and explicit attitude change. Psychol Bull. 2006;132:692-731. https://doi.org/10.1037/0033-2909.132.5.692

140. Hendrick TAM, Fischer ARH, Tobi H, Frewer LJ. Self-reported attitude scales: current practice in adequate assessment of reliability, validity, and dimensionality. J Appl Soc Psychol. 2013;43:1538-52. https://doi.org/10.1111/jasp.12147

141. Siegrist M, Sütterlin B. Importance of perceived naturalness for acceptance of food additives and cultured meat. Appetite. 2017;113:320-6. https://doi.org/10.1016/j.appet.2017.03.019

142. Fairlie S. Meat: a benign extravagance. 1st ed. White River Junction, VT: Chelsea Green; 2010.

143. Rafiq QA, Coopman K, Hewitt CJ. Scale-up of human mesenchymal stem cell culture: current technologies and future challenges. Curr Opin Chem Eng. 2013;2:8-16. https://doi. org/10.1016/j.coche.2013.01.005

144. Melero JM, Al M. In vitro expansion of chondrocytes. In: Reis R, Chiellini E, editors. Topic in tissue engineering. vol.3. 2007.https://www.oulu.fi/spareparts/ebook_topics_in_t_e_vol3/ index.html

145. Tavassoli H, Alhosseini SN, Tay A, Chan PPY, Weng Oh SK, Warkiani ME. Large-scale production of stem cells utilizing microcarriers: a biomaterials engineering perspective from academic research to commercialized products. Biomaterials. 2018;181:333-46. https://doi. org/10.1016/j.biomaterials.2018.07.016

146. Bodiou V, Moutsatsou P, Post MJ. Microcarriers for upscaling cultured meat production. Front Nutr. 2020;7:10. https://doi.org/10.3389/fnut.2020.00010

147. Smetana S, Mathys A, Knoch A, Heinz V. Meat alternatives: life cycle assessment of most known meat substitutes. Int J Life Cycle Assess. 2015;20:1254-67. https://doi.org/10.1007/ s11367-015-0931-6

148. Lynch J, Pierrehumbert R. Climate impacts of cultured meat and beef cattle. Front Sustain Food Syst. 2019;3:5. https://doi.org/10.3389/fsufs.2019.00005

149. McGrath M. Cultured lab meat may make climate change worse [Internet]. BBC News. 2019 [cited 2021 May 7]. http://www.bbc.com/news/science-environment-47283162

150. Specht EA, Welch DR, Rees Clayton EM, Lagally CD. Opportunities for applying biomedical production and manufacturing methods to the development of the clean meat industry. Biochem Eng J. 2018;132:161-8. https://doi.org/10.1016/j.bej.2018.01.015

151. Fang J, Wei Y, Teng X, Zhao S, Hua J. Immortalization of canine adipose-derived mesenchymal stem cells and their seminiferous tubule transplantation.J Cell Biochem. 2017;119:366370. https://doi.org/10.1002/jcb.26574

152. Verbeke W, Sans P, Van Loo EJ. Challenges and prospects for consumer acceptance of cultured meat. J Integr Agric. 2015;14:285-94. https://doi.org/10.1016/S2095-3119(14)60884-4

153. Laestadius LI. Public perceptions of the ethics of in-vitro meat: determining an appropriate course of action. J Agric Environ Ethics. 2015;28:991-1009. https://doi.org/10.1007/s10806015-9573-8

154. Sodhi N. Artificial meat: a new taste sensation? Aust Vet J. 2017;95:19-21.

155. Zhang Y, Mao Y, Li K, Luo X, Hopkins DL. Effect of carcass chilling on the palatability 
traits and safety of fresh red meat. Compr Rev Food Sci Food Saf. 2019;18:1676-704. https:// doi.org/10.1111/1541-4337.12497

156. Shang $X$, Tonsor GT. Sanitary and phytosanitary regulations and international red meat trade. Br Food J. 2019;121:2309-21. https://doi.org/10.1108/BFJ-10-2018-0663

157. Caputo V. Does information on food safety affect consumers' acceptance of new food technologies? The case of irradiated beef in South Korea under a new labelling system and across different information regimes. Aust J Agric Resour Econ. 2020;64:1003-33. https://doi. org/10.1111/1467-8489.12393

158. Fernandes AM, Teixeira OS, Revillion JP, Souza ÂRL. Panorama and ambiguities of cultured meat: an integrative approach. Crit Rev Food Sci Nutr. 2021:1-11. https://doi.org/10.1080/1 0408398.2021.1885006

159. Broad GM. Making meat, better: the metaphors of plant-based and cell-based meat innovation. Environ Commun. 2020;14:919-32. https://doi.org/10.1080/17524032.2020.1725085

160. Catts O, Zurr I. Growing semi-living sculptures: the tissue culture art project. Leonardo. 2002;35:365-70. https://doi.org/10.1162/002409402760181123

161. Kadim IT, Mahgoub O, Baqir S, Faye B, Purchas R. Cultured meat from muscle stem cells: a review of challenges and prospects. J Integr Agric. 2015;14:222-33. https://doi.org/10.1016/ S2095-3119(14)60881-9 